\title{
Silver Decorated Mesoporous Carbons for the Treatment of Acute and Chronic Wounds, in a Tissue Regeneration Context
}

This article was published in the following Dove Press journal: International Journal of Nanomedicine

\author{
Elisa Torre ${ }^{\prime}{ }^{\prime}$ \\ Dimitra Giasafaki ${ }^{2}$ \\ Theodore Steriotis $\mathbb{D D}^{2}$ \\ Clara Cassinelli ${ }^{1}$ \\ Marco Morra (iD) \\ Sonia Fiorilli $\mathbb{D}^{3}$ \\ Chiara Vitale-Brovarone (D) ${ }^{3}$ \\ Georgia Charalambopoulou (1D) 2 \\ Giorgio Iviglia (D)
}

'Nobil Bio Ricerche Srl, Portacomaro 14037, AT, Italy; ${ }^{2}$ National Center for Scientific Research "Demokritos", Athens 1534I, Greece; ${ }^{3}$ Department of Applied Science and Technology, Politecnico di Torino, Torino, Italy
Correspondence: Giorgio Iviglia Email giviglia@nobilbio.it
Introduction: Silver decorated mesoporous carbons are interesting systems that may offer effective solutions for advanced wound care products by combining the well-known antimicrobial activity of silver nanoparticles with the versatile properties of ordered mesoporous carbons. Silver is being used as a topical antimicrobial agent, especially in wound repair. However, while silver shows bactericidal properties, it is also cytotoxic at high concentrations. Therefore, the incorporation of silver into ordered mesoporous carbons allows to exploit both silver's biological effects and mesoporous carbons' biocompatibility and versatility with the purpose of conceiving silver-doped materials in light of the growing health concern in wound care.

Methods: The wound healing potential of an ordered mesoporous carbon also doped with two different loadings of silver nanoparticles ( $2 \mathrm{wt} \%$ and $10 \mathrm{wt} \%$ ), was investigated through a biological assessment study based on different assays (cell viability, inflammation, antibacterial tests, macrophage-conditioned fibroblast and human keratinocyte cell cultures).

Results: The results show silver-doped ordered mesoporous carbons to positively condition cell viability, with a cell viability percentage $>70 \%$ even for $10 \mathrm{wt} \% \mathrm{Ag}$, to modulate the expression of inflammatory cytokines and of genes involved in tissue repair (KRT6a, VEGFA, IVN) and remodeling (MMP9, TIMP3) in different cell systems. Furthermore, along with the biocompatibility and the bioactivity, the silver-doped ordered mesoporous carbons still retain an antibacterial effect, as shown by a maximum of $13.1 \%$ of inhibited area in the Halo test. The obtained results clearly showed that the silver-doped ordered mesoporous carbons exhibit both good biocompatibility and antibacterial effect with enhanced re-epithelialization, angiogenesis promotion and tissue regeneration

Discussion: These findings suggest that the exceptional properties of silver-doped ordered mesoporous carbons could be exploited in the treatment of acute and chronic wounds and that such carbon materials could be potential candidates for use in medical devices for wound healing purposes, in particular, the $10 \mathrm{wt} \%$ loading, as the results showed to be the most effective.

Keywords: ordered mesoporous carbon, silver nanoparticles, metal doped carbons, wound healing, tissue regeneration

\section{Introduction}

Chronic wounds represent a health problem that has devastating consequences for patients and entails major costs to healthcare systems and societies. ${ }^{1}$ Different pathological conditions and co-morbidities can ultimately lead to chronic non-healing wounds, including diabetes, arterial and venous insufficiency, chronic kidney disease, pressure ulcers and infections. ${ }^{2}$ Following a tissue injury, damaged cells in the wound release 
cellular factors that trigger a complex repair process, consisting of a series of distinct (yet overlapping) phases: coagulation and hemostasis, inflammation, proliferation and remodeling. ${ }^{3,4}$ In particular, the innate immune system is the first to be activated and the first promoting a local inflammatory response with the recruitment of several inflammatory cells, including macrophages. Activation of macrophages involves the production of a variety of inflammatory cytokines, responsible for stimulation of the inflammatory response and the correct repair processes. ${ }^{5}$ Activated macrophages by contact with pathogens or different signals, secrete cytokines and chemokines extracellularly, with effects carried out in autocrine, paracrine, exocrine and endocrine manner. ${ }^{6}$ Being chemical communicators between cells and tissues, secreted cytokines exert their actions on different kinds of cells by binding to a specific cell surface receptor, thus activating a signaling cascade that triggers a number of cell-specific functions. A deregulated and prolonged inflammatory phase can definitely lead to the development of chronic wounds, characterized by excessive levels of inflammatory cytokines, higher reactive oxygen species (ROS) production and continuous extracellular matrix degradation, establishing a positive feedback loop that rapidly worsens the clinical picture. ${ }^{2}$ Furthermore, a chronic wound is obviously subject to constant infections, with direct and indirect adverse effects on the patient, leading to delayed healing. ${ }^{7}$ Maintenance of a low bacterial load and a low inflammation profile are the primary goal in the treatment of chronic wounds and, there is a constant pursuit for more effective and efficient approaches. The employment of metallic nanoparticles can be particularly effective in regulating the different phases of the repair process and in promoting a faster wound closure, based on the specific ion properties. ${ }^{8-10}$ Emphasis has been mainly placed so far on silver, which has been widely used in medicine for millennia due to its anti-bacterial and anti-inflammatory activity, having led to a variety of silver-containing formulations. ${ }^{11}$ It has been shown that scaling down silver to the nanoscale $(<100 \mathrm{~nm})$ improves its antimicrobial activity compared with the bulk material due to the higher specific surface area. In general, the use of metallic materials at nanometer length scales, confers to nanoparticles new properties, which depend on the size, ${ }^{12}$ morphology, ${ }^{13}$ structure and crystallinity of the nanomaterial itself, ${ }^{14,15}$ and allows achievement of the required therapeutic effect by optimizing the dose, controlling the release and improving the pharmacokinetics. ${ }^{10}$ Silver nanoparticles can be easily incorporated in support materials, such as metal oxides, polymers as well as nanoporous inorganic materials (silicas, carbons, zeolites). This helps to increase the surface area and promote the activity of silver nanoparticles, towards more effective antimicrobial agents compared to the direct use of silver compounds. Nowadays there is a large number of commercial silver-based dressings, aspiring to be effective against a wide range of bacteria for a prolonged period, that differ significantly with respect to the silver content and type but also support material used. Typical substrates span from alginate, carboxymethylcellulose, collagen, chitosan films, to hydrogels and polyurethane foams. Significant attention has been also given to porous materials such as activated carbons, on the basis of their large surface area and pore volume also allowing for adsorption of toxins and wound-degradation products. However, activated carbons do not have a tunable structure; moreover, they are highly microporous (with pore size less than $2 \mathrm{~nm}$ ) and as such, they are better suited only for retaining small molecules. On this basis, the use of silver-doped mesoporous carbons could represent a novel and effective system for wound healing therapy. Indeed, ordered mesoporous carbon materials, although rarely considered so far in the biomedical sector, are receiving increasing interest for several applications, from controlled delivery and release of therapeutic agents, to bio-imaging, bioadsorption and bio-sensing, thanks to their multiple promising properties combining the advantages of the mesoporous nanostructure and carbonaceous composition: presence of an organized mesoporous network with large surface area, high pore volume and tunable pore size, high chemical and mechanical stability, high biocompatibility, ease of surface modification and ability to act as high-absorbing inert agents. $^{16,17}$ All these properties make ordered mesoporous carbons an attractive versatile system that may be employed in the treatment of pathological conditions, which require a local-sustained therapeutic agent release and the payload can be carried out with several different therapeutic agents (e.g. drugs, ions, biological molecules, nanoparticles). The present work focuses on the investigation of the wound healing and the anti-bacterial potential of an ordered mesoporous carbon such as CMK-3 (comprising carbon rods arranged in a relatively regular two-dimensional hexagonal array), decorated with different amounts of silver nanoparticles. It should nevertheless be noted that the present study does not include detailed antimicrobial studies of silver-doped porous carbons but rather focuses on the ability of the proposed nanocomposites to promote (in vitro) a biological response towards wound healing, while simultaneously retaining their antimicrobial capabilities under complete cytocompatibility. The widely used murine fibroblast L929 cell line was used in this study, due to their easiness of culture and their reproducibility 
in terms of results, in order to assess the cytocompatibility of the tested nanomaterials as indicated in ISO 10993-5: Cytotoxicity. Furthermore, they are fibroblast cells, i.e. the first cell type implicated in the early process of wound healing repopulation. Consequently, the murine macrophage J774a.1 cell line was used to perform both inflammation and co-culture experiments. Nevertheless, since our work focuses on materials for human wounds healing the (human) keratinocyte $\mathrm{HaCaT}$ cell line was used for further studies, because of its well-established biological characteristics: it is an immortal human epithelial cell line from adult skin which maintains full epidermal differentiation capacity and normal keratinocytes' features while it is regarded in literature as an in vitro cell model of the skin epidermal layer. The results obtained from the combination of a wide range of advanced assays (from cell viability, inflammation, antibacterial tests to macrophageconditioned fibroblast and human keratinocyte cell cultures) were very encouraging as they confirmed that the studied silver-doped ordered mesoporous carbons are non-cytotoxic, do not trigger short-term inflammation responses and promote tissue regeneration and angiogenesis meeting key priorities and requirements for the development of effective medical products for acute and chronic wound healing purposes.

\section{Experimental Section Synthesis of Ordered Mesoporous Carbon (CMK-3 Type)}

A CMK-3 type ordered mesoporous carbon (denoted hereafter as C3) was prepared based on a typical nanocasting procedure $^{18,19}$ using the SBA-15 hexagonally ordered mesoporous silica as template and sucrose as carbon precursor. SBA-15 was synthesized via a well-established method ${ }^{20-22}$ using tetraethylorthosilicate (TEOS 98\%, Sigma Aldrich) as silica source and triblock copolymer $\mathrm{EO}_{20} \mathrm{PO}_{70} \mathrm{EO}_{20}$ (Pluronic P123, Sigma Aldrich) as surfactant. The C3 carbon material was obtained through the infiltration of SBA15 with an acidic sucrose solution, and the subsequent carbonization of the composite material at $900^{\circ} \mathrm{C}$ under inert gas flow, followed by the dissolution of the silica framework using hydrofluoric acid at $25^{\circ} \mathrm{C}$.

\section{Synthesis of Ordered Mesoporous Carbon Decorated with Silver Nanoparticles}

The ordered mesoporous carbon $\mathrm{C} 3$ was doped with $\mathrm{Ag}^{0}$ nanoparticles by using two different concentrations of $\mathrm{AgNO}_{3}$ (Merck) as metal source and high-grade $\mathrm{NaBH}_{4}$
(Merck) as reducing agent. A certain amount of the carbon sample was dispersed into de-ionized water, followed by the dropwise addition of an aqueous solution of the metal precursor. The mixture remained under stirring at room temperature for $24 \mathrm{hrs}$. $\mathrm{NaBH}_{4}$ was added approximately $1 \mathrm{hr}$ before filtration, after which the obtained solid was washed meticulously and dried at $40^{\circ} \mathrm{C}$. The silver-doped carbon samples are denoted hereafter as $\mathrm{C} 3 \mathrm{Ag} 2$ and $\mathrm{C} 3 \mathrm{Ag} 10$, corresponding to a metal loading of ca. $2 \mathrm{wt} \%$ and $10 \mathrm{wt} \%$, respectively.

\section{Characterization of Pristine and Silver-Doped Mesoporous Carbons}

The powder X-ray diffraction (PXRD) patterns of the samples were obtained using a Rigaku R-AXIS IV Imaging Plate Detector mounted on a Rigaku RU-H3R Rotating Copper Anode X-ray Generator $(\lambda=1.54 \AA)$.

A Jeol JSM 7401F Field Emission Scanning Electron Microscope (SEM) equipped with Gentle Beam mode was used to study the surface morphology of the doped materials as well as the size and the dispersion of the metal particles. The transmission electron microscope (TEM) images were obtained from a high resolution JEM-2100 instrument equipped with $\mathrm{LaB}_{6}$ filament and operating at $200 \mathrm{kV}$ using the LowDose procedure provided by the JEOL software. A SETARAM SETSYS Evolution 18 Analyzer and $\mathrm{Al}_{2} \mathrm{O}_{3}$ crucibles were used to perform the thermogravimetric analysis (TGA) measurements on $\sim 10 \mathrm{mg}$ of the $\mathrm{Ag}$-doped and undoped samples, in the range of $25-1100^{\circ} \mathrm{C}$, with a heating rate of $20^{\circ} \mathrm{C} / \mathrm{min}$ under air flow $(16 \mathrm{~mL} / \mathrm{min})$. Buoyancy corrections were carried out through blank measurements and purging was applied well before initiating thermal analysis to efficiently control the sample environment within the furnace.

A volumetric gas adsorption analyzer (Autosorb-1-MP, Quantachrome) was used to evaluate the porous properties of the doped and undoped materials by $\mathrm{N}_{2}$ adsorption/desorption measurements at $77 \mathrm{~K}$. The samples $(\sim 30 \mathrm{mg})$ were appropriately outgassed $\left(\sim 24 \mathrm{hrs}\right.$ at $\left.250^{\circ} \mathrm{C}\right)$ under high vacuum $\left(10^{-6}\right.$ mbar), while ultra-pure $\mathrm{N}_{2}(99.999 \%)$ was used. The BET (Brunauer-Emmett-Teller) area values (denoted as $\mathrm{S}_{\mathrm{BET}}$ ) were calculated by following the BET consistency criteria (ISO 9277:2010). The micropore volumes $\left(\mathrm{V}_{\text {micro }}\right)$ were assumed to be the QSDFT derived cumulative volumes for pores smaller than $2 \mathrm{~nm}$. The total (micro- and mesopore) volumes (TPV) were estimated at $\mathrm{p} / \mathrm{p}_{0}=0.96$. Pore size distributions (PSD) were deduced by using the $\mathrm{N}_{2-}$ carbon QSDFT (Quenched Solid Density Functional Theory) 
kernels for slit/cylindrical-shaped pores on the adsorption branch of the isotherms. The concentration of silver ions released from both Ag-doped CMK-3 samples was evaluated by soaking the powders in Tris $\mathrm{HCl}$ buffer Tris(hydroxymethyl)aminomethane (Trizma-Sigma Aldrich, Milan, Italy - $0.1 \mathrm{M}, \mathrm{pH} 7.4$ ) at a concentration of $250 \mu \mathrm{g} /$ $\mathrm{mL}$. In particular, $5 \mathrm{mg}$ of the $\mathrm{C} 3 \mathrm{Ag} 2$ and $\mathrm{C} 3 \mathrm{Ag} 10$ powders were suspended in $20 \mathrm{~mL}$ of buffer up to 14 days at $37^{\circ} \mathrm{C}$ in an orbital shaker (Excella E24, Eppendorf) with an agitation rate of $150 \mathrm{rpm}$. At defined time points ( $3 \mathrm{hrs}, 24 \mathrm{hrs}, 3$ days, 7 days and 14 days) the suspension was centrifuged at 10,000 rpm for $5 \mathrm{~min}$ (Hermle Labortechnik Z326, Wehingen, Germany), half of the supernatant was collected and replaced by the same volume of fresh buffer solution to keep constant the volume of the release medium. The release experiments were carried out in triplicate. The concentration of $\mathrm{Ag}^{+}$ions was measured by Inductively Coupled Plasma Atomic Emission Spectrometry Technique (ICP-AES) (ICPMS, Thermo Scientific, Waltham, MA, USA, ICAP Q). The overall supernatants recovered after centrifugation have been diluted at a dilution factor of 2 before ICP measurements.

\section{Cell Viability Assay}

The cell viability test was performed through Transwell ${ }^{\circledR}$ inserts, characterized by a given permeability. In particular, the murine fibroblast cell line L929 BS CL 56 (IZSLER) was cultured in polystyrene plates below $1 \mathrm{mg} \cdot \mathrm{mL}^{-1}$ suspension of C3Ag2 and C3Ag10 contained in the Transwell ${ }^{\circledR}$ insert and after 72 hrs of incubation, MTT assay was performed to evaluate cell viability. MTT assay allows the assessment of any eventual toxic effect on cells induced by particle dissolution products, through the evaluation of the reduction of the mitochondrial succinate dehydrogenase (SDH) enzyme activity, which is involved in the citric acid cycle. To perform the MTT assay, cells were incubated at $37^{\circ} \mathrm{C}$ for $2 \mathrm{hrs}$ with $1 \mathrm{mg} \cdot \mathrm{mL}^{-1}$ solution of soluble tetrazolium salt (3-(4,5-dimethylthiazol-2yl)-2,5 diphenyl tetrazolium bromide), to allow the succinate dehydrogenase enzyme to cause the transformation of tetrazolium salts into a yellow soluble substance first and then into a blue water-insoluble product, the formazan precipitate. This blue product, dissolved with dimethylsulphoxide, can be spectrophotometrically quantified at a wavelength of $570 \mathrm{~nm}$, providing an optical density (OD) value, a measure of the degree of the enzyme activity in the metabolically active cells. The negative control was represented by cells grown on the polystyrene plate, while the positive one was set up with a culture of cells grown with the addition of $20 \mu \mathrm{L}$ of a solution of $0.08 \mathrm{mg} \cdot \mathrm{mL}^{-1}$ of sodium nitroprusside (NPS).

\section{Inflammatory Test Cell Culture}

The inflammatory response test was conducted in direct contact mode, by incubating the murine macrophage cell line J774a.1 BS TCL 83 (Istituto zooprofilattico sperimentale della Lombardia e dell'Emilia Romagna - IZSLER) with both $\mathrm{C} 3 \mathrm{Ag} 2$ and $\mathrm{C} 3 \mathrm{Ag} 10$ samples at $1 \mathrm{mg} \mathrm{mL}-1$ concentration. Before the tests, cells were maintained in Dulbecco's modified Eagle's medium (Gibco Invitrogen, Cergy-Pontoise, France) supplemented with 10\% fetal bovine serum, penicillin $\left(100 \mathrm{U} \cdot \mathrm{mL}^{-1}\right)$ and streptomycin $\left(100 \mu \mathrm{g} \cdot \mathrm{mL}^{-1}\right)$. Cells were grown in a $98 \%$ humidified incubator at $37^{\circ} \mathrm{C}$ with $10 \% \mathrm{CO}_{2}$ and passaged $2-3$ days before use. Then, the J774a. 1 cells $\left(2 \times 10^{4} \mathrm{~mL}^{-1}\right)$ were seeded onto 24-well tissue culture polystyrene plates (Falcon ${ }^{\mathrm{TM}}$ ), containing the two silver-doped C3 samples.

\section{RT-qPCR}

After 4 hrs, RNA from J774a.1 cells was isolated by using the Maxwell $^{\circledR}$ RSC simply RNA Cells Kit (Promega Italia s.r.l, Milan, Italy) and reverse transcribed by the High-Capacity cDNA Reverse Transcription Kit (Applied Biosystems, Foster City, CA, USA). Real-time PCR was performed through the QuantStudio ${ }^{\circledR} 5$ Real Time PCR System (Applied Biosystems). Mouse interleukin-1 $\beta$ (IL-1 $\beta$ ), interleukin-6 (IL-6), tumor necrosis factor-alpha (TNF $\alpha$ ) and tyrosine 3-monooxygenase/tryptophan 5-monooxygenase activation protein zeta (YWHAZ) were chosen from the collection of the TaqMan Gene Expression Assays as primer sets (Applied Biosystems Assay's ID: Mm01336189_m1, Mm999990 64_m1, Mm00443258_m1, Mm03950126_s1, respectively). Real-time PCR was performed in duplicate for all samples in a volume of $25 \mu \mathrm{L}$ and, after an initial denaturation at $95^{\circ} \mathrm{C}$ for $10 \mathrm{~min}$, the PCR amplification was run for 40 cycles at $95^{\circ} \mathrm{C}$ for $15 \mathrm{~s}$ and at $60^{\circ} \mathrm{C}$ for $1 \mathrm{~min}$. The content of cDNA samples was normalized through the comparative threshold cycle $(\Delta \Delta \mathrm{Ct})$ method, consisting in the normalization of the number of target gene copies versus the endogenous reference gene YWHAZ.

\section{Macrophage-Conditioned Fibroblast Cell Culture Macrophage Cell Culture}

The murine macrophage cell line J774a.1 BS TCL 83 (IZSLER) was maintained in Dulbecco's modified 
Eagle's medium+GlutaMAX (Gibco Invitrogen, CergyPontoise, France) supplemented with 10\% fetal bovine serum, penicillin $\left(100 \mathrm{U} \cdot \mathrm{mL}^{-1}\right)$ and streptomycin $(100$ $\left.\mu \mathrm{g} \cdot \mathrm{mL}^{-1}\right)$. Cells were grown in a $98 \%$ humidified incubator at $37^{\circ} \mathrm{C}$ with $10 \% \mathrm{CO}_{2}$ and passaged 2-3 days before use. Then, the J774a.1 cells $\left(8 \times 10^{4} \mathrm{~mL}^{-1}\right)$ were seeded into ThinCert ${ }^{\mathrm{TM}}$ cell culture inserts (Greiner Bio-One), placed into 12-well tissue culture polystyrene plates (Sarstedt Srl), containing the two silver-doped C3 samples at $1 \mathrm{mg} \cdot \mathrm{mL}^{-1}$ concentration. After $48 \mathrm{hrs}$ incubation, 500 $\mu \mathrm{L}$ of macrophage-conditioned medium (M $\phi \mathrm{CM})$ were taken from the bottom of the wells and used to conditioning a fibroblast cell culture.

\section{Fibroblast Cell Culture}

The murine fibroblast cell line L929 BS CL 56 (IZSLER) was maintained in Minimum Essential media+GlutaMAX (Gibco Invitrogen, Cergy-Pontoise, France), supplemented with $10 \%$ fetal bovine serum, penicillin $\left(100 \mathrm{U} \cdot \mathrm{mL}^{-1}\right)$ and streptomycin $\left(100 \mu \mathrm{g} \cdot \mathrm{mL}^{-1}\right)$. Cells were grown in a $98 \%$ humidified incubator at $37^{\circ} \mathrm{C}$ with $10 \% \mathrm{CO}_{2}$ and passaged 2-3 days before use. Then, L929 cells $\left(8.2 \times 10^{4} \mathrm{~mL}^{-1}\right)$ were seeded onto 12-well tissue culture polystyrene plates (Sarstedt $\mathrm{Srl}$ ) and incubated for $48 \mathrm{hrs}$ after the addition of $500 \mu \mathrm{L}$ MфCM.

\section{RT-qPCR}

After 48 hrs incubation, RNA from J774a.1 and L929 cells was isolated by using the Maxwell ${ }^{\circledR}$ RSC simplyRNA Cells Kit (Promega), following the manufacturer's instructions. RNA has been reverse transcribed by the High-Capacity cDNA Reverse Transcription Kit (Applied Biosystems). Realtime PCR was performed in the QuantStudio ${ }^{\circledR} 5$ Real Time PCR System (Applied Biosystems). The primer sets for the Real-time PCR of mouse IL-1 $\beta$, IL-6, TNF $\alpha$, Vascular endothelial growth factor A (VEGFA), Fibroblast growth factor 2 (FGF2), Epidermal growth factor (EGF), Transforming growth factor beta 1 (TGF- $\beta 1$ ), Collagen type 1, alpha 1 chain (Col1a1), Matrix metalloproteinase-9 (MMP9), Tissue inhibitor of Metalloproteinases 3 (TIMP3), Osteopontin (Spp1), Microtubule-associated proteins 1A/1B light chain 3B (MAP1LC3b), Beclin 1 (Becn1), Mammalian target of rapamycin (mTOR), Sequestosome-1 (p62), Glyceraldehyde 3-phosphate dehydrogenase (GAPDH) and YWHAZ were chosen from the TaqMan Gene Expression Assays collection (Applied Biosystems Assay's ID: Mm01336189_m1, Mm99999064_m1, Mm00443258_m1, Mm00437306_m1, Mm00433287_m1, Mm00438696_m1,
Mm 01178820_m1, Mm00801666_g1, Mm00442991_m1, Mm00441826_m1, Mm00436767_m1, Mm00782868_sH, Mm01265461_m1, Mm00444968_m1, Mm00448091_m1, Mm033002249_g1 and Mm03950126_s1, respectively). RTqPCR was performed in duplicate for all samples and targets in a total volume of $25 \mu \mathrm{L}$. The analysis was conducted by using the $\Delta \Delta \mathrm{C}_{\mathrm{T}}$ method, consisting in the normalization of the number of target gene copies versus the endogenous reference gene YWHAZ, for J774a.1 cells and versus the endogenous reference genes GAPDH and YWHAZ, for L929 cells.

\section{Direct Effects of Silver-Doped Mesoporous Carbons on Keratinocytes Cell Culture}

The test was conducted in direct contact mode by incubating the human keratinocyte cell line HaCaT BS CL 168 (IZSLER) with the two silver-doped C3 samples (C3Ag2 and $\mathrm{C} 3 \mathrm{Ag} 10)$ in direct contact at $1 \mathrm{mg} \cdot \mathrm{mL}^{-1}$ concentration. Cells were maintained in Dulbecco's modified Eagle's medium+GlutaMAX (Gibco Invitrogen, CergyPontoise, France), supplemented with $10 \%$ fetal bovine serum, penicillin (100 $\left.\mathrm{U} \mathrm{mL}^{-1}\right)$ and streptomycin (100 $\left.\mu \mathrm{g} \cdot \mathrm{mL}^{-1}\right)$. Cells were grown in a $98 \%$ humidified incubator at $37^{\circ} \mathrm{C}$ with $10 \% \mathrm{CO}_{2}$ and passaged 2-3 days before use. $5 \times 10^{4} \mathrm{~mL}^{-1} \mathrm{HaCaT}$ cells were seeded into 24-well tissue culture polystyrene plates (Falcon ${ }^{\mathrm{TM}}$ ). When cells reached sub-confluence, the silver-doped C3 samples were placed in direct contact with cells.

\section{RT-qPCR}

After 24 and 72 hrs incubation, RNA from HaCaT cells was isolated by using the Maxwell ${ }^{\circledR}$ RSC simplyRNA Cells Kit (Promega) as described in Section 2.6.3. The primer sets for the Real-time PCR of human matrix metalloproteinase-9 (MMP9), Tissue inhibitor of Metalloproteinases 3 (TIMP3), Vascular endothelial growth factor A (VEGFA), Transforming growth factor-beta 1 (TGF- $\beta 1$ ), Keratin 6a (KRT6a), Involucrin (IVN) and Tyrosine 3-Monooxygenase/Tryptophan 5-Monooxygenase Activation Protein Zeta (YWHAZ) (Applied Biosystems Assay's ID: Hs00234579_m1; Hs00165949_m1, Hs00900055_m1; Hs00998133_m1; Hs01699178_g1; Hs00846307_s1; Hs03044281_g1, respectively) were chosen from the TaqMan Gene Expression Assays collection (Applied Biosystems). RT-qPCR was performed in duplicate for all samples and targets in a total volume of $25 \mu \mathrm{L}$. The analysis was conducted by using the $\Delta \Delta \mathrm{C}_{\mathrm{T}}$ method, consisting in the normalization of the number of target gene copies versus the endogenous reference gene YWHAZ. 


\section{Antibacterial Assay}

The antibacterial assay was performed on the $\mathrm{C} 3 \mathrm{Ag} 2$ and C3Ag10 samples by using a Gram-positive bacterial strain. In particular, Staphylococcus epidermidis RP62A (ATCC 35984) was chosen because of its ability to produce a slime and capsular polysaccharide. The strain is routinely kept in Tryptic Soy Agar (TSA, Sigma). Prior to the assay, it is transferred to Tryptic Soy Broth (TSB, Sigma) and left to grow overnight. After centrifugation at $5000 \mathrm{rpm}$ for 10 mins, TSB supernatant is removed and the bacterial pellet is re-suspended in Dulbecco's Phosphate Buffered Saline (DPBS, Gibco), to obtain a $10 \times 10^{9} \mathrm{~mL}^{-1}$ bacterial suspension; then, $10 \mathrm{~mL}$ bacterial suspension is added in $1000 \mathrm{~mL}$ cooled, still not solidified, TSA. The assay was conducted in 6-wells plates (Sarstedt), in which each well contained $7 \mathrm{~mL} \mathrm{TSA}+$ S. epidermidis. On the solidified agar surface, $500 \mu \mathrm{g} \mathrm{mL}^{-1}$ and $1000 \mu \mathrm{g} \mathrm{mL}^{-1}$ silver-doped $\mathrm{C} 3$ carbons were spotted, in duplicate. The negative control was represented by the Agar gel without the addition of bacteria, nor the $\mathrm{C} 3$ carbons, whereas the positive control was the Agar gel with bacteria, but without $\mathrm{C} 3$ carbons. The 6-wells plates were then incubated at $37^{\circ} \mathrm{C}$ for $72 \mathrm{hrs}$. The percentage of the inhibition zone was calculated using ImageJ (1.49v, Wayne Rasband, National Institute of Health, USA) software, comparing the total area of the single well with the area inhibited by the release of silver.

\section{Statistical Analysis}

Experimental data were analyzed using $\mathrm{PAST}^{23}$ and results are reported as mean (standard deviation) (S.D.) from 3 independent experiments ( 3 wells for each set of data). Statistical differences between groups were analyzed using one-way or two-way ANOVA, followed by Tukey's post

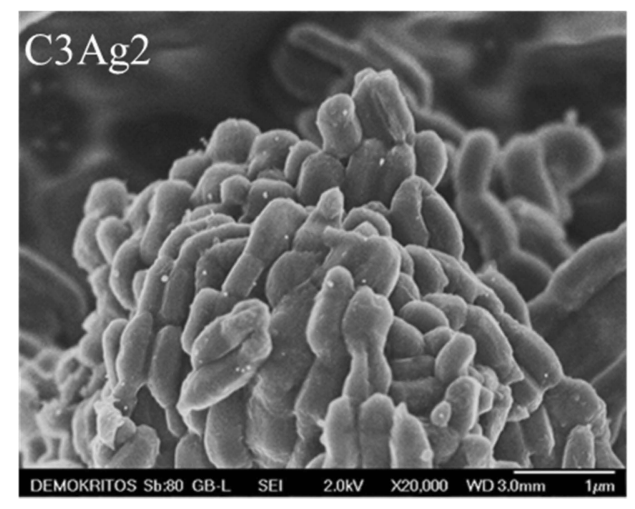

Figure I SEM images of C3Ag2 and $\mathrm{C} 3 \mathrm{Ag} I 0$. hoc. Results with $p$ values $\leq 0.05$ were considered to be statistically significant.

\section{Results and Discussion}

Morphology and Structure of the Pristine and Silver-Doped Mesoporous Carbons

SEM analysis of the silver-doped C3 samples (Figure 1) revealed on one hand that they exhibit the typical elongated morphology of CMK-3 carbons ${ }^{24}$ with mean diameter of 200-300 nm and length around $0.5-1 \mu \mathrm{m}$ and on the other that Ag nanoparticles (with an average size of 25 $\mathrm{nm}$ ) are highly dispersed on the carbonaceous surface with only very few aggregates.

Similarly, the TEM images (Figure 2) of the silverdoped $\mathrm{C} 3$ samples with $2 \mathrm{wt} \%$ and $10 \mathrm{wt} \%$ Ag loading, confirmed the successful dispersion of small $(<10 \mathrm{~nm})$ nanosized metal particles; however, the presence of larger particles $(20-30 \mathrm{~nm})$ is also observed.

The existence of $\mathrm{Ag}^{0}$ nanoparticles onto the carbon surface and thus the biphasic nature of the composite materials was also verified by the wide-angle PXRD patterns of the silver-doped carbons as shown in Figure 3A. The two well-resolved peaks at around $2 \theta=38.2^{\circ}$ and $2 \theta=44.3^{\circ}$ are in good agreement with those of the facecentered-cubic form of metallic silver (JCPDS, File No. 4-0783), ${ }^{25,26}$ while no reflections of other crystalline phases like $\mathrm{AgO}$ or $\mathrm{Ag}_{2} \mathrm{O}$ were observed. The mean size of the Ag nanoparticles was calculated to be around 25-30 $\mathrm{nm}$ (by applying Scherrer's formula on the (111) diffraction peaks), in agreement with SEM and TEM analyses. The lattice constant calculated from the PXRD patterns was found to be $\mathrm{a}=0.408 \mathrm{~nm}$, which is consistent with the literature value for $\operatorname{Ag}(111)$. The low-intensity broad peak at approximately $2 \theta=26^{\circ}$ (attributed to the (002) reflection

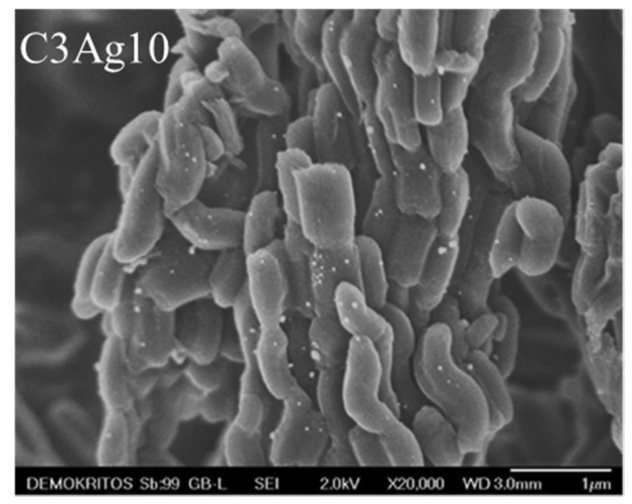



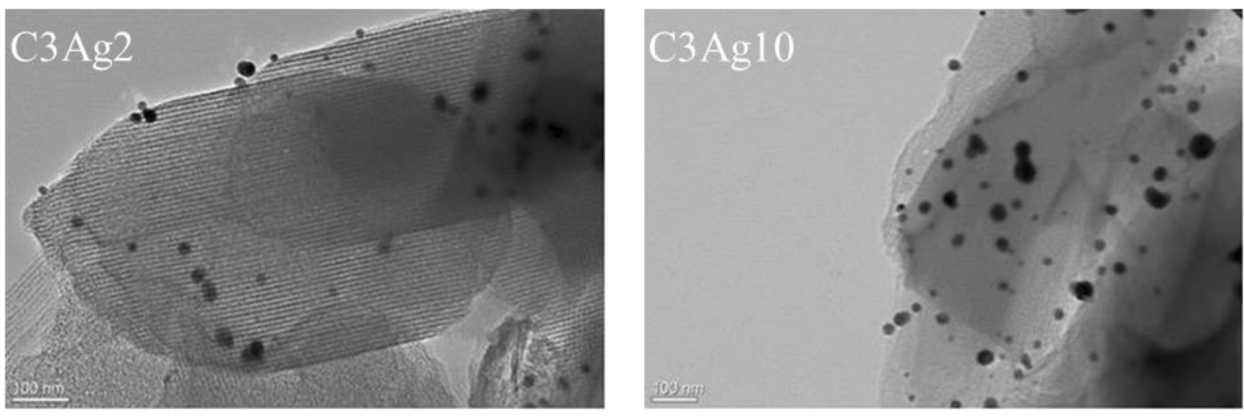

Figure 2 TEM images of C3Ag2 and C3AgIO.
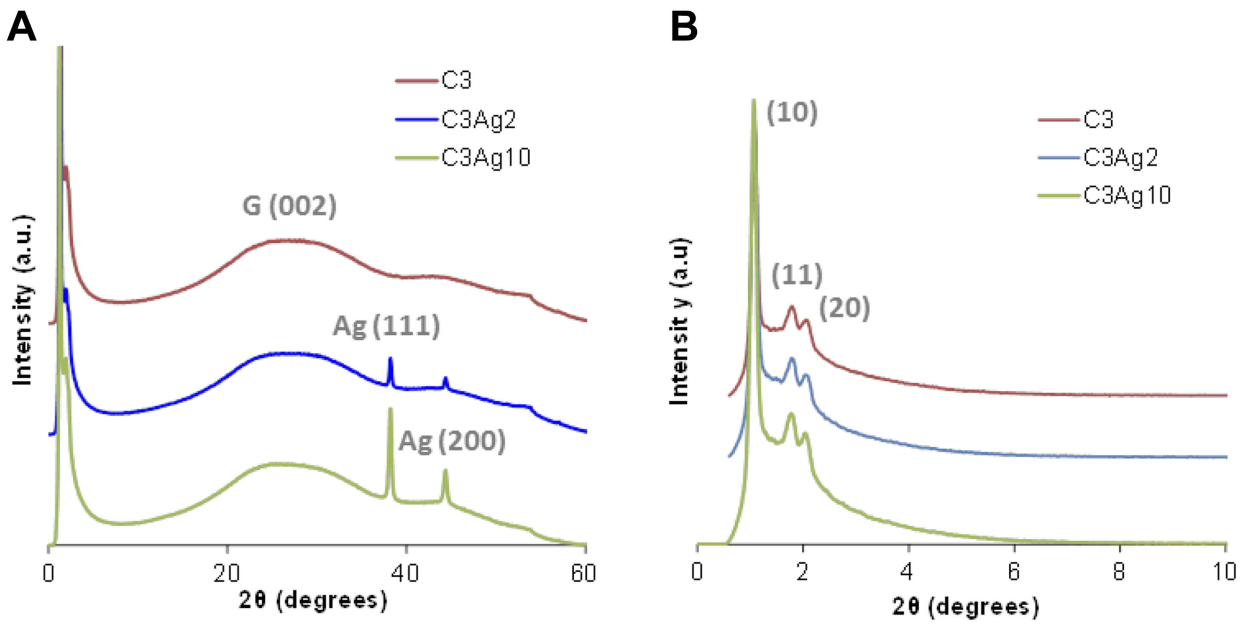

Figure 3 (A) Wide- and (B) small-angle PXRD patterns of the doped and undoped carbons.

of graphite), in all wide-angle PXRD patterns, indicated the predominantly amorphous structure of the $\mathrm{C} 3$ material.

The small-angle PXRD pattern of the C3 sample was typical of the $2 \mathrm{D}$ hexagonal space group $(p 6 \mathrm{~mm}) .{ }^{19}$ More specifically, the small-angle PXRD pattern of the C3 sample (Figure 3B) depicted an intense peak at around $2 \theta=1.1^{\circ}$ attributed to (10) reflection, as well as weaker peaks centered at around $2 \theta=1.8^{\circ}$ and $2.1^{\circ}$ that can be indexed to (11) and (20) reflections, respectively. These three peaks represent a well-organized arrangement of the carbon nanorods and therefore of the pores of the $\mathrm{C} 3$ samples. As also shown in Figure 3B, the metal doping treatment did not seem to affect the highly ordered mesoporous structure of the C3 carbon, since there was no significant degradation nor broadening of the main peak and/or the higher-order reflections in the case of the silver-doped samples.

The pore properties of the carbon materials were determined by $\mathrm{N}_{2}$ adsorption-desorption measurements at 77 $\mathrm{K}$. The obtained isotherms, as well as the corresponding pore size distributions (PSD), are shown in Figure 4. The isotherms of the materials were of type IV (based on IUPAC classification) with $\mathrm{H} 2$ hysteresis loop, typical for mesoporous materials like CMK-3 with uniform mesopores. ${ }^{19}$ The increase of the $\mathrm{N}_{2}$ uptake at $\mathrm{p} / \mathrm{p}_{0}>0.96$ for all samples could be ascribed to nitrogen condensation in the interparticle voids, indicating the presence of external surface/macroporosity.

The pore properties of all samples are summarized in Table 1. The almost identical shape of the $\mathrm{N}_{2}$ sorption isotherms of the pristine and silver-doped carbon materials indicate that the basic features of the pore structure were retained after doping. The slight decrease of the BET area and the total pore volume observed upon metal doping (Table 1) could be attributed to the extra weight of the Ag nanoparticles. More specifically, by taking into consideration the amount of metallic silver (as deduced from the TGA measurements presented in section 3.2) the calculated surface area and pore volume values on a pure carbon basis, remained practically unchanged after the incorporation of the metal particles, thus pointing to minimal pore blocking. 


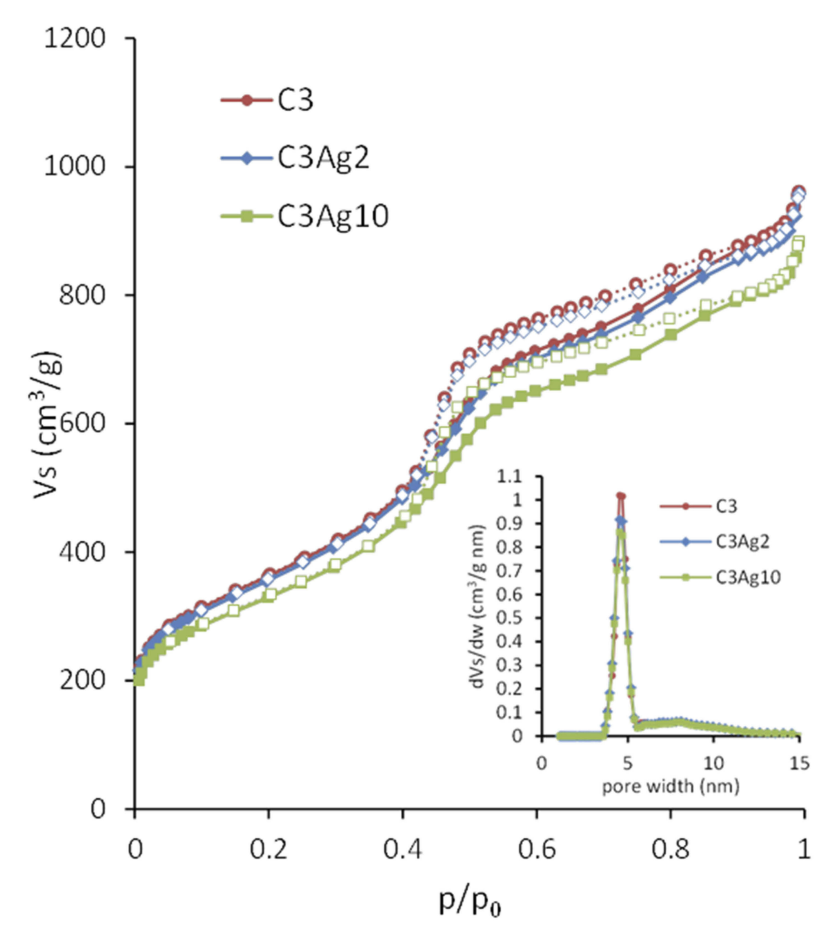

Figure $4 \mathrm{~N}_{2}$ adsorption-desorption isotherms of $\mathrm{C} 3, \mathrm{C} 3 \mathrm{Ag} 2$ and $\mathrm{C} 3 \mathrm{Ag} 10$ (inset: PSD).

\section{Metal Loading of the Silver-Doped Mesoporous Carbons}

Thermal analysis of the doped C3 samples (Figure 5) revealed a significant weight loss in the temperature range of $400-600^{\circ} \mathrm{C}$, during oxidation/decomposition of the samples, which corresponds to complete carbon burn-off. The loading amount of metallic silver on the samples was deduced by the final residual mass. The Ag loading, as estimated on dry sample basis $\left(120^{\circ} \mathrm{C}\right)$, was found to be $9.86 \mathrm{wt} \%$ for the C3Ag10 sample and $2.29 \mathrm{wt} \%$ for the $\mathrm{C} 3 \mathrm{Ag} 2$ sample. The results also indicated some sort of catalytic effect of the silver nanoparticles on $\mathrm{C} 3$ oxidation since the increased Ag loading led to a lower burn-off temperature.

\section{$\mathrm{Ag}^{+}$Ion Release from the Silver-Doped Mesoporous Carbons}

Figure 6 shows the release of $\mathrm{Ag}^{+}$ion from carbons containing different silver amount. As expected C3Ag10

Table I Pore Properties of C3, C3Ag2 and C3AgIO

\begin{tabular}{|l|l|l|l|l|l|}
\hline & $\begin{array}{l}\mathbf{S}_{\text {BET }} \\
\left(\mathbf{m}^{2} / \mathbf{g}\right)\end{array}$ & $\begin{array}{l}\text { Total Pore } \\
\text { Volume } \\
\left(\mathbf{c m}^{3} / \mathbf{g}\right)\end{array}$ & $\begin{array}{l}\mathbf{V}_{\text {micro }} \\
\left(\mathbf{c m}^{3} / \mathbf{g}\right)\end{array}$ & $\begin{array}{l}\mathbf{V}_{\text {meso }} \\
\left(\mathbf{c m}^{3} / \mathbf{g}\right)\end{array}$ & $\begin{array}{l}\text { Pore } \\
\text { Width } \\
(\mathbf{n m})\end{array}$ \\
\hline C3 & 1291 & 1.4 & 0.1 & 1.3 & 4.5 \\
C3Ag2 & 1270 & 1.3 & 0.1 & 1.2 & 4.5 \\
C3Ag10 & 1171 & 1.2 & 0.1 & 1.1 & 4.5 \\
\hline
\end{tabular}

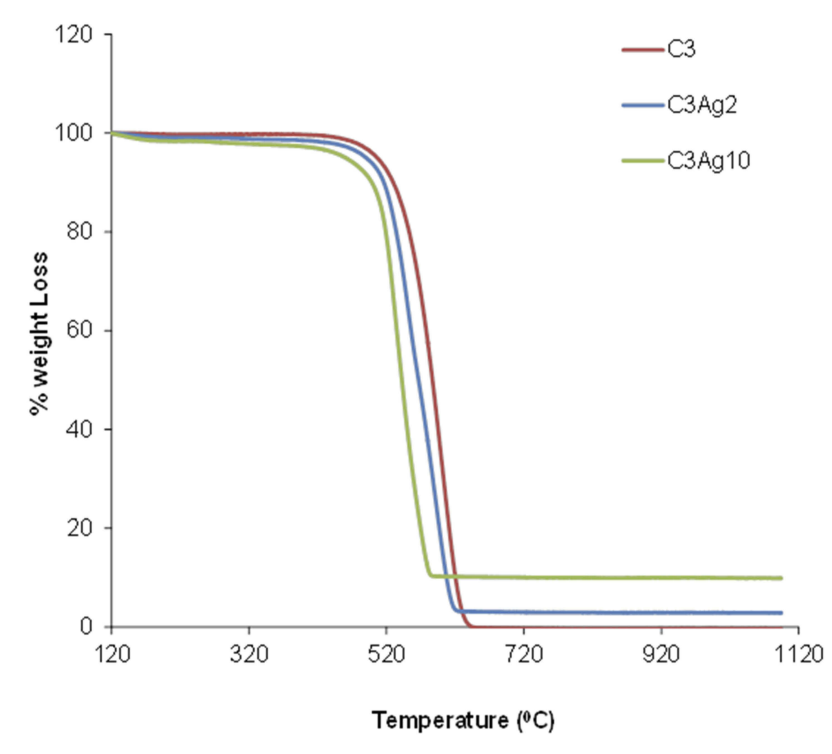

Figure 5 TGA analysis of the doped and undoped carbons.

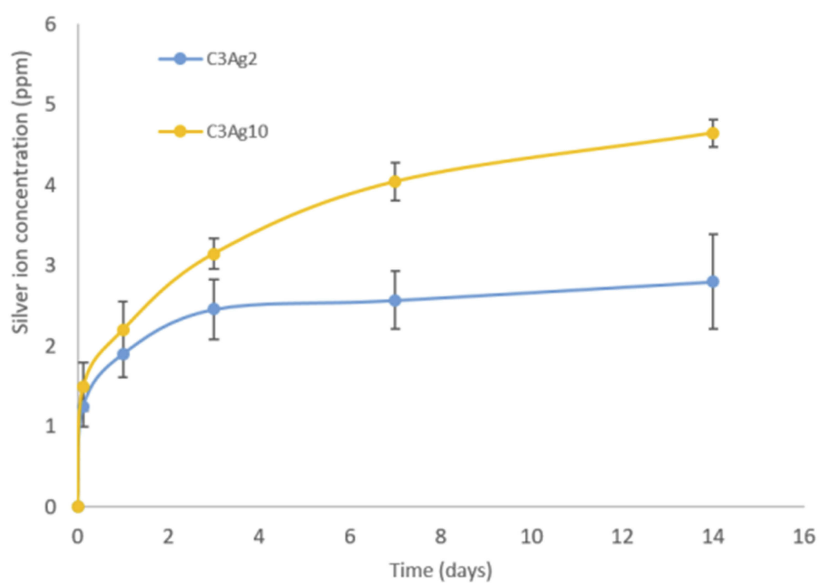

Figure 6 Silver ion release from Ag-doped carbons.

released higher ion concentrations, compared to $\mathrm{C} 3 \mathrm{Ag} 2$, and showed a sustained release profile up to 14 days. The released concentrations analyzed after 14 days of soaking were $2.8 \mathrm{ppm}$ and $4.6 \mathrm{ppm}$, respectively, for C3Ag2 and C3Ag10. Based on the initial amount loaded on carbons, the percentage of silver released at 14 days resulted in about $55 \%$ for $\mathrm{C} 3 \mathrm{Ag} 2$ and $18 \%$ for $\mathrm{C} 3 \mathrm{Ag} 10$, evidencing their long-term release ability. The obtained $\mathrm{Ag}^{+}$species' released concentrations are in fair agreement with those reported in the literature related to silver-containing nanocarriers proposed for the treatment of infected tissues, ${ }^{27}$ which resulted in highly effective in vivo against bacteria while preserving full biocompatibility. 


\section{Cell Viability Assay}

The cell viability assay results showed that $\mathrm{C} 3$ and $\mathrm{C} 3 \mathrm{Ag} 2$ do not exert any significant change in cell metabolic activity and thus do not impair the mitochondrial function despite the presence and release of silver, whereas, silverdoped $\mathrm{C} 3$ at the highest Ag concentration, caused a slight decrease in cell viability, which however was still maintained above $70 \%$ (Figure 7).

The good cell biocompatibility of both silver-doped C3 materials that was observed in the present study was further confirmed by the inflammation test, showing both inflammatory and anti-inflammatory effects in two experiments carried out at two different time points.

\section{Inflammation Test}

Specifically, at $4 \mathrm{hrs}$ incubation, the silver-doped C3 materials did not induce, in macrophages, any significant increase in pro-inflammatory cytokines' expression (Figure 8). The inflammation test was performed by incubating, for $4 \mathrm{hrs,} \mathrm{in}$

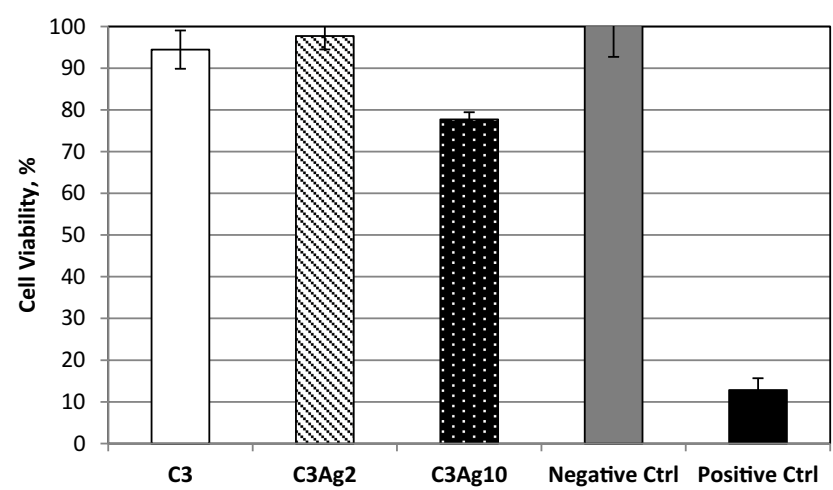

Figure 7 MTT assay on pristine C3 and its silver-doped analogues with 2 wt\% or $10 \mathrm{wt} \% \mathrm{Ag}^{0}$.

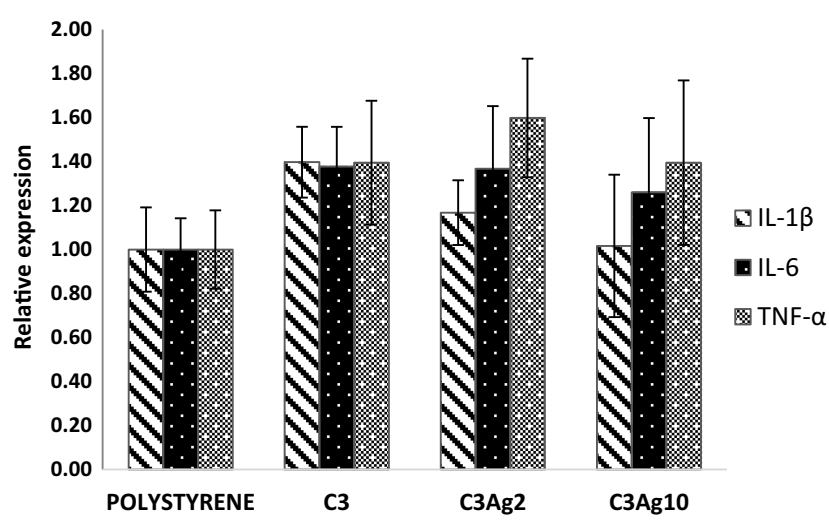

Figure 8 Effect of silver-doped mesoporous carbons on the expression of proinflammatory cytokines mRNA. No significant difference can be observed in the inflammation test. direct contact, the silver-doped $\mathrm{C} 3$ samples $\mathrm{C} 3 \mathrm{Ag} 2$ and C3Ag10 with the J744a.1 macrophage cell line.

\section{Indirect Cellular Effects of the Silver-Doped Mesoporous Carbons on Fibroblast Cells}

To investigate the potential role of macrophage-secreted factors induced by the silver-doped ordered mesoporous carbon C3 in promoting tissue regeneration, L929 murine fibroblasts were cultured, for $48 \mathrm{hrs,}$ with the addition of $500 \mu \mathrm{L}$ M $\phi C M$ obtained from $48 \mathrm{hrs}$ incubation of J774a.1 macrophages with and without $\mathrm{C} 3 \mathrm{Ag} 2$ or $\mathrm{C} 3 \mathrm{Ag} 10$ into Transwell ${ }^{\circledR}$ inserts.

J774a.1 were first checked for pro-inflammatory cytokine mRNA production, following stimulation by the silverdoped C3 materials. Figure 9 shows the expression of proinflammatory cytokines such as IL- $1 \beta$, IL- 6 and TNF- $\alpha$. Results showed increased IL-6 mRNA levels in cells incubated with all carbonaceous nanomatrices $(2.8,2.7,3.1$-fold in $\mathrm{C} 3, \mathrm{C} 3 \mathrm{Ag} 2$ and $\mathrm{C} 3 \mathrm{Ag} 10$, respectively) and $\mathrm{C} 3 \mathrm{Ag} 10$ inducing also a statistically significant peak of IL-1 $\beta$ (3.3-fold $p<0.01$ ), thus implying activation of macrophages by direct contact with the silver-doped $\mathrm{C} 3$ materials. A proinflammatory effect induced by both silver-doped $\mathrm{C} 3$ materials at $48 \mathrm{hrs}$, highlighted by an increase in IL- 6 expression at the same extent, could be attributed to the $\mathrm{C} 3$ itself, which, synergistically with the highest $\mathrm{Ag}$ dose, also contributes to the enhancement of IL-1 $\beta$ expression.

These opposite effects on inflammation, at $4 \mathrm{hrs}$ and $48 \mathrm{hrs}$ reflect those reported by many works (in which both activation of the inflammatory pathways ${ }^{28-31}$ and downregulation of proinflammatory cytokines ${ }^{32,33}$ are demonstrated in vitro and in vivo) and could be of particular interest in a wound healing context, because an immediate short-term increase of inflammation, followed by downregulation, are the main signals required for an effective wound healing process. As highly tunable materials, silver-doped mesoporous carbon materials could be tailored to achieve the desired tissue regeneration function, to be applied in a variety of pathological conditions, from acute wounds to ulcers and burn wounds. Such immune modulation by silver-doped $\mathrm{C} 3$ materials is of great importance as they can offer the base for the subsequent wound healing phases, in which fibroblast migration and deposition of newly synthesized extracellular matrix occur. In fact, several works report Ag nanoparticles inducing higher collagen expression, ${ }^{34}$ promoting re-epithelialization through increased cell migration and proliferation ${ }^{35}$ and accelerating wound closure. ${ }^{35,36}$ 


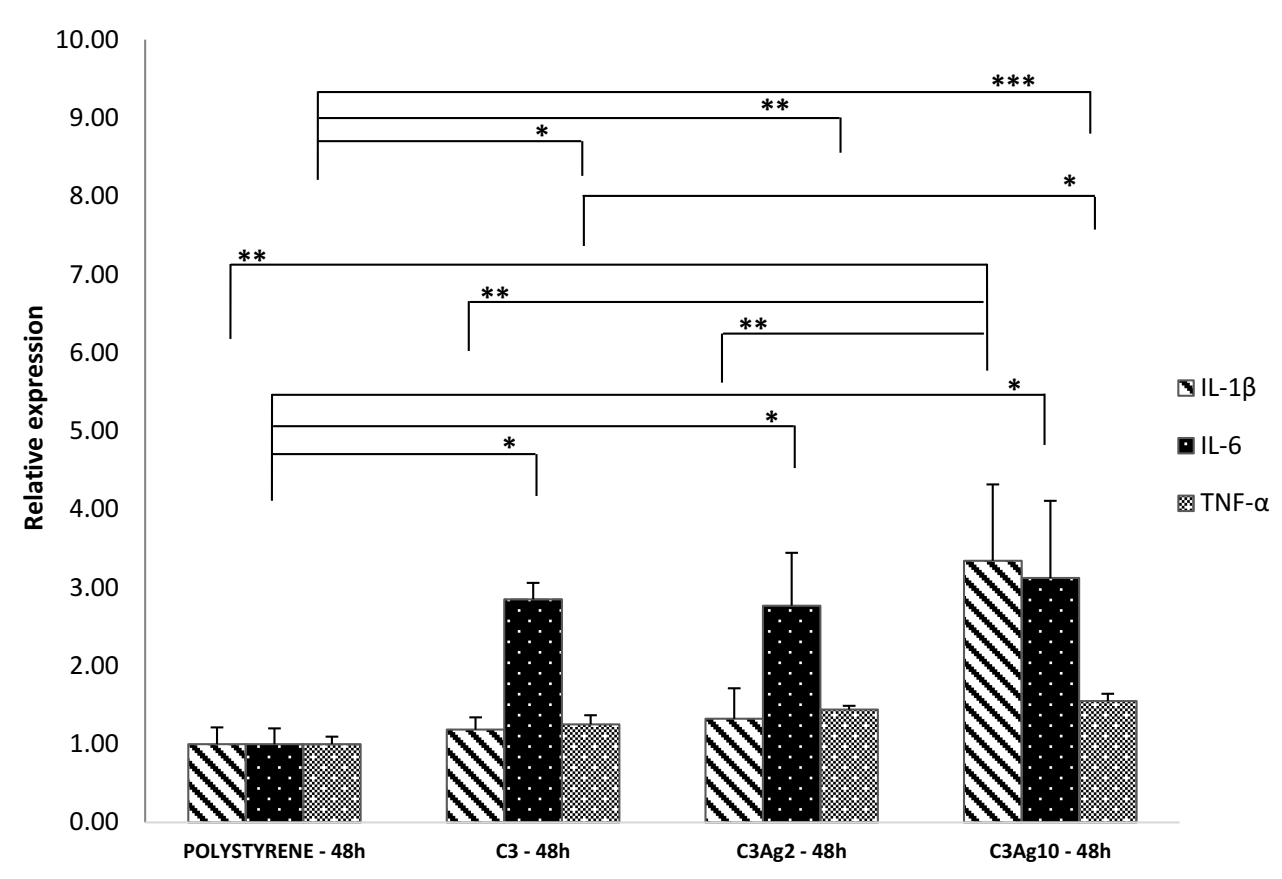

Figure 9 Gene expression analysis of J774al macrophage cells incubated into Transwell ${ }^{\circledR}$ inserts with ordered mesoporous carbon C3 doped with or without Ag 2 wt $\%$ and $\mathrm{Ag} 10 \mathrm{wt} \%$. All three C3 nanomatrices (pristine and silver-doped) induced enhanced IL- 6 and TNF- $\boldsymbol{\alpha}$ expression, compared to polystyrene, whereas an increase of IL-I $\boldsymbol{\beta}$ levels is only seen in C3Ag I0-stimulated J774a. I macrophages, at 48 hrs incubation time. Data are expressed as mean (SD). P values $\leq 0.05$ were considered to be statistically significant $(* p \leq 0.05 ; * * p \leq 0.01 ; * * * p \leq 0.001)$.

Given that macrophages were shown to be activated by C3 nanomatrices (with and without Ag) with proinflammatory cytokines' production, $500 \mu \mathrm{L}$ M $\phi C M$ were added to a fibroblast cell culture and RT-qPCR was performed after $48 \mathrm{hrs}$ incubation time. Expression of the main tissue repair genes, such as FGF, EGF, TGF- $\beta 1$, Colla1, Spp1, VEGFa, MMP-9 and TIMP-3 were investigated, in order to evaluate the wound healing potential of the pristine and silver-doped mesoporous carbons (Figure 10).

In particular, TGF- $\beta$ and Colla1 were 1,27 and 1,34-fold higher than polystyrene (both $p<0,05$ ), while for TIMP3 levels an increase of 1,78-fold compared to polystyrene was estimated $(p<0,05$ compared to polystyrene and to $\mathrm{C} 3 \mathrm{Ag} 2 ; p<0.01$ compared to $\mathrm{C} 3$ ). Among the several released growth factors, the TGF- $\beta$ isoforms do exert fundamental and pleiotropic actions in the wound healing process, by promoting the inflammatory phase and recruiting different cells, which subsequently express genes involved in inflammation and in extracellular matrix (ECM) formation. ${ }^{37}$ TGF$\beta 1$ isoform has been demonstrated to be involved in the main healing processes: inflammation, ${ }^{38}$ angiogenesis, ${ }^{39}$ fibroblast proliferation, ${ }^{40,41}$ extracellular matrix remodeling and regeneration. ${ }^{42}$ Furthermore, it promotes direct collagen type I synthesis and indirect collagen I accumulation through inhibition of MMPs $^{43}$ and through enhanced TIMPs expression, thus switching the MMPs/TIMPs ratio in favor of TIMPs. ${ }^{44,45}$ After taking a look at the present inflammation results obtained at $48 \mathrm{hrs}$, it is clear that the determining factor could reside in the different pro-inflammatory profile induced by the highest dose of $\mathrm{Ag}$, as compared to $\mathrm{C} 3 \mathrm{Ag} 2$. In fact, the higher IL-1 $\beta$ expression can induce TGF- $\beta 1$ expression $^{46}$ which, in turn, can act as negative modulator of the immune system ${ }^{47,48}$ and as the main cytokine involved in the regulation of ECM gene expression. ${ }^{42}$ These results demonstrate the ability of $\mathrm{C} 3 \mathrm{Ag} 10$ to induce, in macrophages, a late inflammatory profile involved in the signals necessary for ECM production.

Given the above promising results, it was decided to further investigate the role of the silver-doped C3 materials in the regulation of autophagy. Real-time PCR was performed to investigate the expression of genes involved in autophagy: Microtubule-associated proteins 1A/1B light chain 3B (MAP1LC3b), Beclin-1 (Beclin1), Sequestosome1 (p62) and Mammalian target of rapamycin (mTOR).

In the context of wound healing, autophagy is important in regulating a correct inflammation resolution and vascularization, through secretion of VEGF; ${ }^{49}$ furthermore, it has been shown to be involved in preventing burn wound progression, $^{50}$ in promoting burn wound healing through reducing the cellular apoptotic rate, ${ }^{51}$ in promoting a faster 


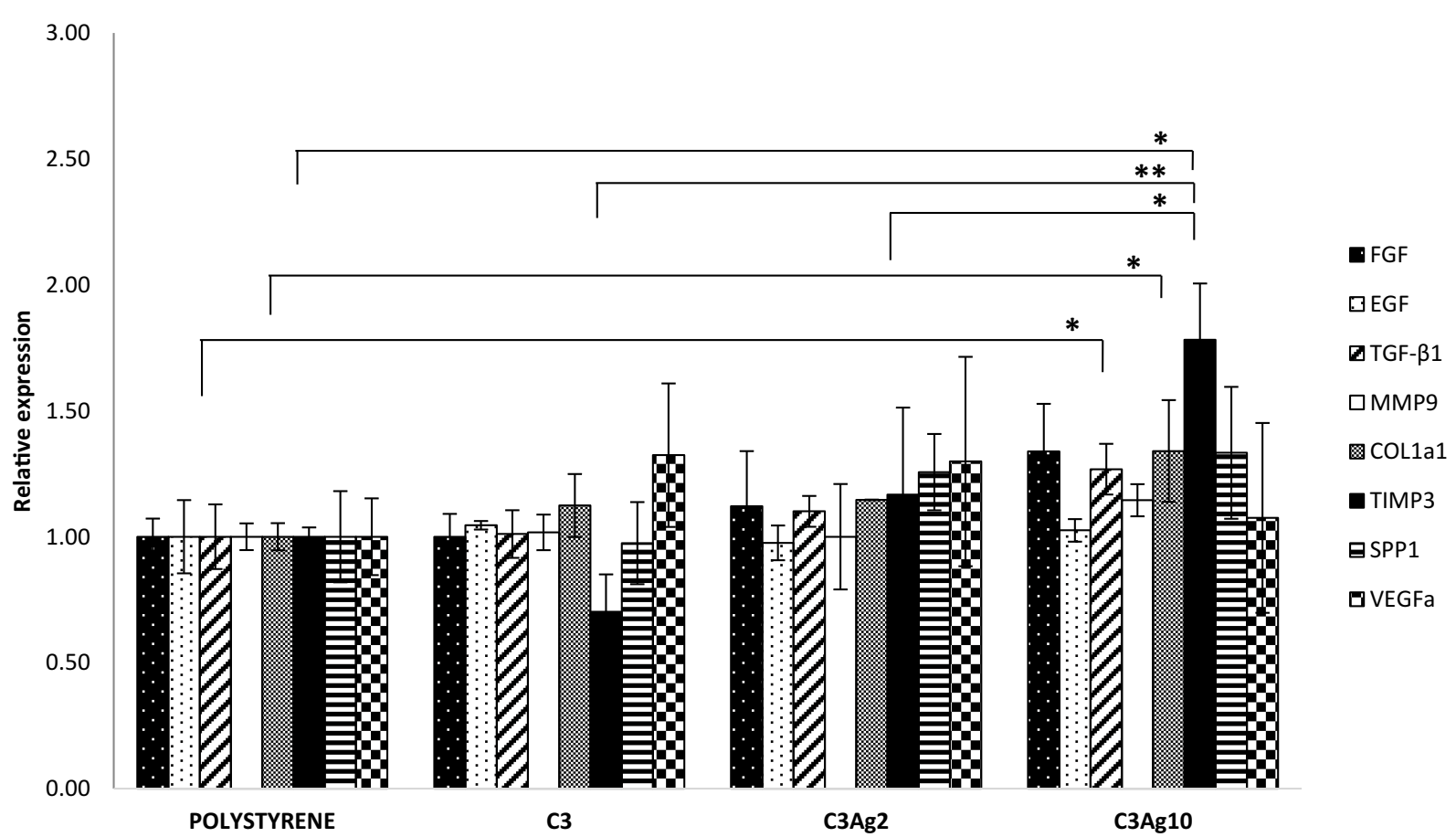

Figure 10 Gene expression analysis of L929 fibroblast cells incubated for 48 hrs with the addition of $500 \mu \mathrm{L}$ M $\$$ CM. Only M\$CM from J774a.I incubated with C3Ag 10 was shown to be effective, in L929, in stimulating the expression of genes involved in a tissue regeneration response. Data are expressed as mean (SD). P values $\leq 0.05$ were considered to be statistically significant $\left({ }^{*} p \leq 0.05 ;{ }^{* *} p \leq 0.0 \mathrm{I}\right)$.

re-epithelialization in rats ${ }^{52}$ and in regulating the fibrosis of hypertrophic scars in dermal fibroblasts. ${ }^{53}$ According to literature silver nanoparticles may be involved in both inducing ${ }^{54}$ and blocking autophagy. ${ }^{55}$
The obtained results (Figure 11) showed an increase of mTOR mRNA levels in cells incubated with C3Ag10, statistically significant if compared to polystyrene $(1,15-$ fold $-p<0,05)$ and to pristine $\mathrm{C} 3(p<0,05)$, thus paving the

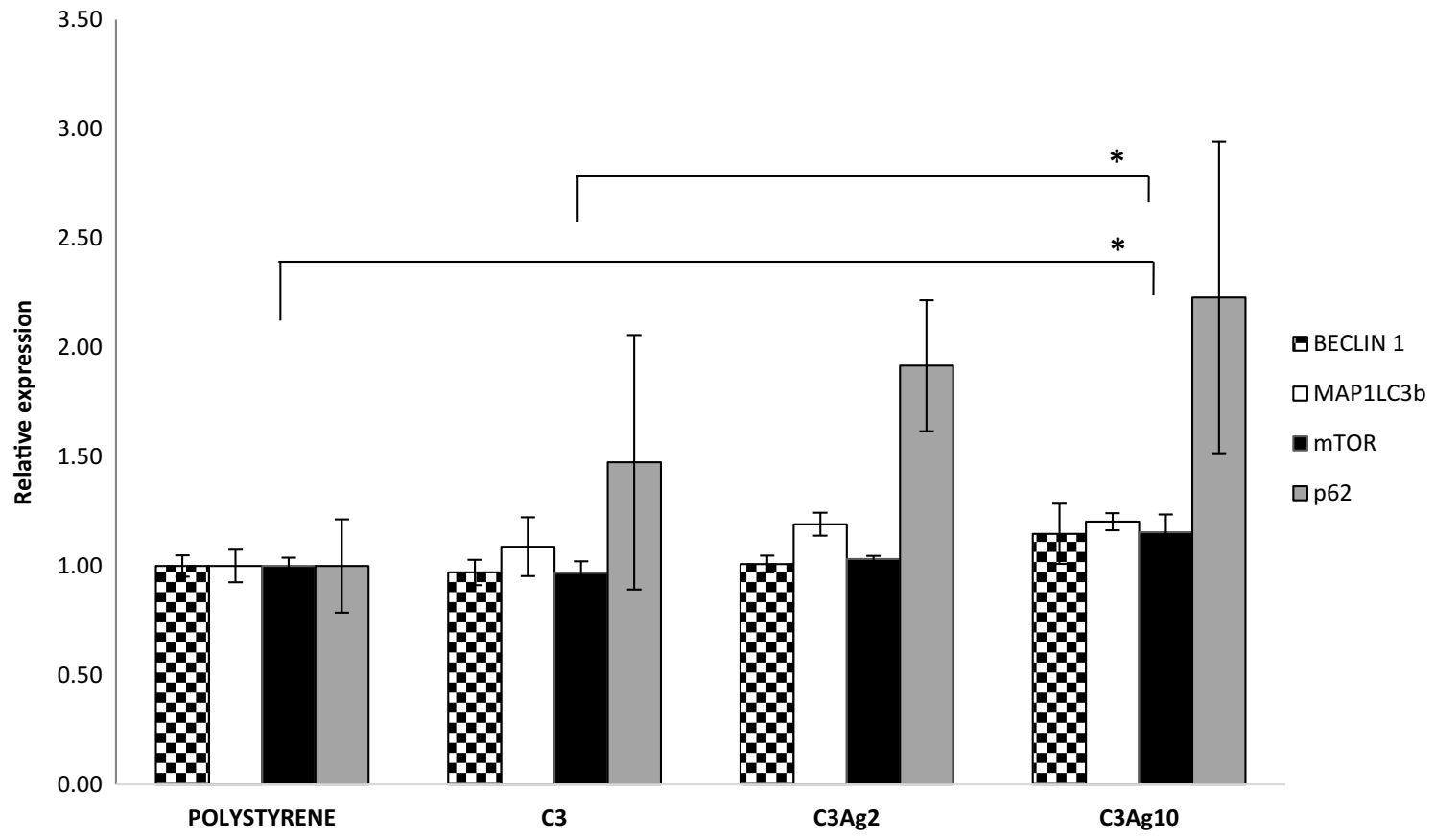

Figure II RT-qPCR autophagy results from L929 cells cultured with the addition of $500 \mu \mathrm{L}$ conditioning medium from J774a.I cells grown inside inserts with silver-doped C3 materials. Data are expressed as mean (SD). P values $\leq 0.05$ were considered to be statistically significant $\left({ }^{*} p \leq 0.05\right)$. 
way to further investigate mesoporous silver-doped carbons in the field of autophagy involved in burn treatment. A parallel expression increase, even if not statistically significant, could be observed also for MAP1LC3b and for p62 genes in samples incubated with C3, C3Ag2 and C3Ag10, with the highest value found in C3Ag10 samples.

\section{Direct Cellular Effects of the Silver-Doped Mesoporous Carbons on Keratinocytes}

To better understand the direct wound healing potential of silver-doped C3 materials, they were incubated, in direct contact with the human immortalized keratinocyte $\mathrm{HaCaT}$ cell line, recognized, moreover, as a suitable model for assessing the toxicological potential of nanomaterials that can cause skin damage in vitro. ${ }^{56}$ The effect of C3Ag2 and $\mathrm{C} 3 \mathrm{Ag} 10$, at a concentration of $1 \mathrm{mg} \cdot \mathrm{mL}^{-1}$ on expression of genes involved in wound repair, such as VEGFA, KRT6a, TGF- $\beta$, MMP9, TIMP3 and IVN, in HaCaT cells, was studied by RT-qPCR at two different time points analysis, namely $72 \mathrm{hrs}$ and 7 days (Figure 12A and B).

Current treatments suggest that wound healing better occur when a faster re-epithelialization is achieved and, in this field, silver nanoparticles have been shown to stimulate keratinocyte proliferation, migration and differentiation. ${ }^{35,57}$ In the context of tissue repair following an injury, keratinocytes are an important type of cells involved in the reepithelialization process, being able to undergo changes in their morphology and gene expression during the so-called "keratinocyte activation", in which a particular subtype of them withdraw from terminal differentiation stages to more undifferentiated ones. $^{58}$

Keratinocytes express different keratin (K) types, depending on their differentiation stage: basal cells express $\mathrm{K} 5$, K14 and K15, whereas during the differentiation process these keratins are switched off, being replaced by $\mathrm{K} 1$ and K10. A particular group of keratins includes K6, K16 and $\mathrm{K} 17$, representing inducible keratins produced in response to signals that determine activation of the keratinocytes, particularly in a wound healing context. ${ }^{59}$ Specifically, K6 is induced after only $1 \mathrm{hr}$ following an injury $^{60}$ and its reduced expression has been linked to delayed wound healing, ${ }^{61}$ because its expression coincides with the onset of re-epithelialization.

Activated keratinocytes show a different behavior from differentiated keratinocytes; in fact, they have been shown to have a different organization of keratin filaments, ${ }^{62}$ to change their cytoskeleton to migrate to the wound site, to undergo hyperproliferation in order to produce components of the basement membrane and to express high levels of cell surface receptors. Furthermore, activated keratinocytes are also able to communicate with different cell types, such as fibroblasts, lymphocytes and endothelial cells through the production of paracrine and/or autocrine signals. All these changes are essential for the correct reepithelialization. ${ }^{63}$

In our study, analysis of K6 gene expression showed that both silver-doped C3 materials induce a slight upregulation at $72 \mathrm{hrs}$, further confirmed at 7 days. In particular, the presence of $\mathrm{Ag}$, at $72 \mathrm{hrs}$, did not seem to influence K6 expression, while at 7 days both $\mathrm{C} 3 \mathrm{Ag} 2$ and $\mathrm{C} 3 \mathrm{Ag} 10$ induce a statistically significant increase (2.04 and 1.78fold $-p<0.001$ and $p<0.01$, respectively), as compared to polystyrene at 7 days (Figure 12A). These results clearly indicate that silver-doped $\mathrm{C} 3$ materials are able to induce the keratinocyte activation stage.

Concerning TGF- $\beta 1$ expression, results showed that it was slightly affected at 7 days in $\mathrm{C} 3 \mathrm{Ag} 2$ and $\mathrm{C} 3 \mathrm{Ag} 10$ samples (0.66 and 0.72-fold, respectively), even if statistically not significant. In intact epidermis, TGF- $\beta 1$ isoform contributes to skin homeostasis through inhibition of keratinocyte proliferation and regulation of differentiation. ${ }^{64}$

As keratinocytes undergo more differentiated stages, they express differentiation markers such as involucrin (IVN), an essential protein for the formation of the cornified envelope, produced in the early spinous layer and maintained in the granular layer until the corneum envelope is formed. ${ }^{65}$ The presence of several reactive Glutamine residues in the protein represents the ideal substrate, for the Transglutaminase 1, to form covalent isopeptide bonds, important for the cornified envelope formation. In fact, the cross-linking process makes the cell envelope insoluble and, thus, highly resistant. Transglutaminases are $\mathrm{Ca}^{2+}$-dependent enzymes that catalyze an acyl transfer reaction between the $\Upsilon$-carboxamide group of protein-bound glutamines and the $\epsilon$-amino group of lysine residues. ${ }^{66}$ Calcium is the key factor needed for the cross-linking reaction to take place and for the correct keratinocyte differentiation process. ${ }^{67}$ In a wound healing context, keratinocytes are recruited to the wound edge, to begin the re-epithelialization process.

As compared to polystyrene, cells incubated with the silver-doped C3, irrespective of Ag concentration, showed dramatically downregulation of IVN expression, at both time points. Particularly, for cells incubated with neat $\mathrm{C} 3$ nanomatrices and $\mathrm{C} 3 \mathrm{Ag} 2$ and $\mathrm{C} 3 \mathrm{Ag} 10$ (Figure 12A), 

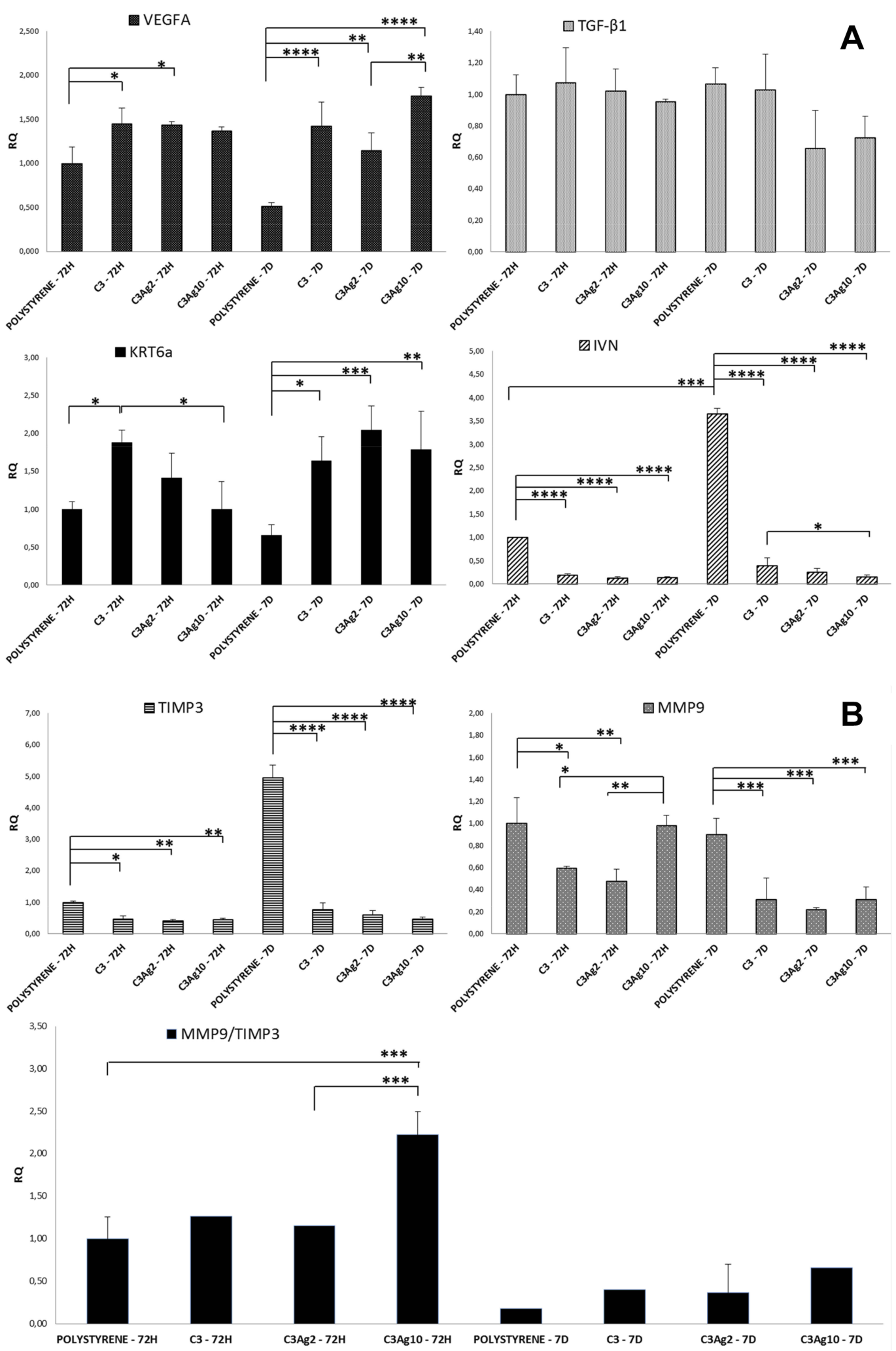

Figure 12 (A) and (B) Gene expression profile of $\mathrm{HaCaT}$ cells following incubation with C3Ag2 or C3AgIO. RT-qPCR analysis of $\mathrm{HaCaT}$ cells at 72 hrs and 7 days incubation with C3Ag2 or C3AgIO shows an increase in the expression of genes involved in tissue repair and a decrease in the expression of MMP9. The diminished IVN expression levels show that cells incubated with $\mathrm{C} 3$ are kept in a more undifferentiated stage as compared to polystyrene. Data are expressed as mean (SD). P values $\leq 0.05$ were considered to be statistically significant $\left({ }^{*} \mathrm{p} \leq 0.05 ; *^{*} \leq 0.01 ; * * * p \leq 0.00 \mathrm{I} ; * * * *_{p} \leq 0.000 \mathrm{I}\right)$. 
downregulation at $72 \mathrm{hrs}$ was $0.2,0.13$ and 0.14 -fold $(p<0.0001)$, while at $7 \mathrm{~d}$ it was $0.39,0.36$ and 0.13 -fold, respectively $(p<0.0001)$.

The marked downregulation of IVN expression, observed in $\mathrm{HaCaT}$ cells treated with silver-doped $\mathrm{C} 3$ materials, clearly demonstrate the ability of these materials to keep keratinocytes in more undifferentiated stages, thus contributing to enhanced re-epithelialization. This difference in IVN expression in cells incubated with silver-doped C3 materials, could be explained with a decrease of $\mathrm{Ca}^{2+}$ levels in the culture medium caused by a possible $\mathrm{Ca}^{2+}$ ions sequestration by silver-doped C3 materials (e.g. by means of direct adsorption in the pores), thus inducing cells to retain a basal phenotype. ${ }^{68}$

The expression of MMP9 and TIMP3 was also investigated. Metal nanoparticles have already been shown to have a role in tissue remodeling through modulating the expression of Metalloproteinases (MMPs) and tissue inhibitors of metalloproteinases (TIMPs).

Both were shown to be downregulated in cells incubated with $\mathrm{C} 3$ and $\mathrm{C} 3 \mathrm{Ag} 2$ at $72 \mathrm{hr}(0.59$ and 0.48 -fold $-p<0.05$ and $p<0.01$ for MMP9; 0.47 and 0.41 -fold $-p<0.05$ and $p<0.01$ for TIMP3, respectively), while C3Ag10 induced only downregulation of TIMP3 (0.44-fold $-p<0.01)$, with an MMP9/ TIMP3 ratio significantly unbalanced in favor of MMP9 (2.25-fold $-p<0.001)$. At $7 \mathrm{~d}$ time point, however, this ratio was switched in favor of TIMP3, both in control and in cells treated with silver-doped C3 materials. Differently from control cells, those incubated with silver-doped $\mathrm{C} 3$ materials exhibited a higher MMP9/TIMP3 ratio, with C3Ag10 inducing the lowest TIMP3 levels (statistically not significant) (Figure 12B). Interestingly, the presence of $\mathrm{C} 3$ carbon seems to be the determining factor in lowering MMP-9 expression.

MMPs are a family of enzymes involved in many physiological processes, such as innate and adaptive immunity, inflammation, angiogenesis, bone remodeling and neurite growth, although their function was thought to be restricted to tissue remodeling and maintenance. ${ }^{69}$ MMPs have also been demonstrated to have a role in the regulation of the repair processes that are activated following an injury. In particular, they are essential in inflammation, thanks to their effects on chemokine activity, on the formation of a chemotactic gradient and on diapedesis. ${ }^{70}$ MMP-9, also known as gelatinase B, is also involved in the regulation of re-epithelialization, in fact, it has been shown to induce epidermal growth factor (EGF) and hepatocyte growth factor (HGF), both important in keratinocyte migration in wound assays in vitro. ${ }^{71}$ Furthermore, MMP-9 is also induced following stimulation by TNF- $\alpha$ and its increase is essential for the correct wound closure, ${ }^{72}$ while it is also involved in the promotion of angiogenesis. ${ }^{73}$ As MMPs elicit different important actions, they need to be tightly regulated by TIMPs; in fact, they are able to counteract MMPs effects by acting on inflammation and on the repair mechanisms. TIMP3, being an inhibitor of ADAM17 activity, inhibits TNF- $\alpha$ release and, consequently, MMP-9 expression. ${ }^{74}$ In addition to its ability to regulating ECM remodeling, TIMP3 has also been shown to inhibit angiogenesis, through binding and blocking the vascular endothelial growth factor receptor (VEGFR)-2, ${ }^{75}$ in order to stabilize newly formed vessels. ${ }^{76}$ In the context of tissue repair and regeneration, also VEGFA has been investigated, because of its main role in mediating proangiogenesis, but also in influencing various mechanisms involved in cutaneous wound healing, such as wound closure, granulation tissue formation and stimulation of different cells, i.e. keratinocytes. ${ }^{77}$ Silver nanoparticles have been also reported to increase vascular endothelial growth factor A (VEGFA) expression, ${ }^{28,78}$ probably following ROS production, the transient or low levels of which are involved in the process of angiogenesis. ${ }^{79,80}$ Several studies in literature report ability of different nanomaterials in exerting pro-angiogenic effects. In particular, gene expression analysis results concerning increased VEGF show Copper, Cerium or Yttriumcontaining nanoparticles to act through an hypoxia-induced mechanism, ${ }^{81-83}$ whereas $\mathrm{ZnO}$ or Europium hydroxide nanoparticles to act through direct Ros generation. ${ }^{84,85}$

Silver-doped C3 materials showed a significant VEGFA increase in transcript levels, as compared to untreated cells at both time points, in comparison to polystyrene, particularly at 7 days $(1.42,1.14$ and 1.76-fold $-p<0.0001 ; p<0.01$; $p<0.0001$ for $\mathrm{C} 3, \mathrm{C} 3 \mathrm{Ag} 2$ and $\mathrm{C} 3 \mathrm{Ag} 10$, respectively), thus showing their angiogenic potential as well (Figure 12A).

\section{Antibacterial Assay}

In addition to their effects on tissue regeneration, silver nanoparticles have also been shown to possess broadspectrum antibiotic properties, ${ }^{86,87}$ thanks to silver's ability to bind to the bacterial cell wall and cell membrane, thus inhibiting membrane functions and the bacterial respiratory chain. ${ }^{88}$ The antibacterial effect of the pristine and silver-doped $\mathrm{C} 3$ materials was investigated using the Halo test on a gram-positive bacteria (Staphylococcus epidermidis) culture, which represents the most common source of infections on indwelling medical devices such as prosthetic devices and IV catheters by producing biofilms. ${ }^{89}$ Given the results from the work of PazosOrtiz et al which reported that Gram-negative bacteria 
present a scarce thickness of the cell wall which increases the susceptibility of these bacteria to silver ions released by nanoparticles, it was decided to perform this preliminary antibacterial test with a Gram-positive strain which is, instead, more resistant to silver ions, due to its thick peptidoglycan cell wall, which limits the uptake of nanoparticles. ${ }^{90}$ The antibacterial test performed in this study, showing the formation of a silver dose-dependent inhibition zone surrounding C3Ag2 and C3Ag10 samples (Figure 13 and Table 2), further verifies the suitability of silver-doped C3 materials as possible medical devices to be employed for the healing of infected wounds. Following these preliminary results, aimed at providing an overview of silver-doped nanoporous carbons' conserved antibacterial effect, further studies will be performed to show the antimicrobial activity in detail.

\section{Conclusion}

Overall, the present study showed that mesoporous silverdoped carbons are not only biocompatible, as they were shown to be non-cytotoxic, but they also do not elicit short-term inflammation responses. Notably, they exhibited clear in vitro biological activity while maintaining both cytocompatibility and the silver-induced antibacterial effect. In particular, the promising gene expression analysis results show that CMK3-type carbon materials doped with silver, especially at $10 \mathrm{wt} \%$, show good potential to contribute to the main wound healing phases. Further studies are needed to fully confirm that the observed results are indicative of the promotion of cellular recruitment and migration, tissue remodeling and angiogenesis. Results presented in this study showed the investigated composites to be particularly promising systems and tools for the treatment of acute and chronic wounds, in a tissue regeneration context.

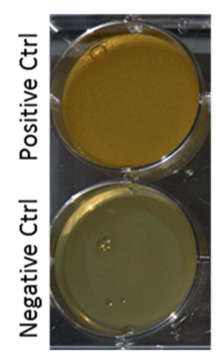

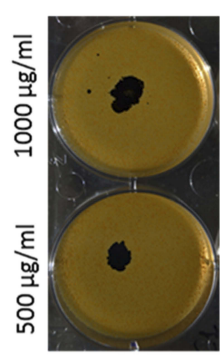

C3

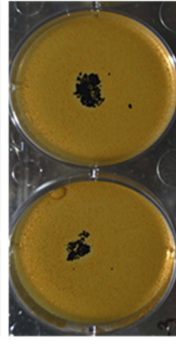

C3Ag2

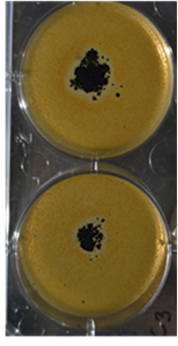

C3Ag10
Figure 13 Halo test of $\mathrm{C} 3, \mathrm{C} 3 \mathrm{Ag} 2$ and $\mathrm{C} 3 \mathrm{Ag} 10$ on $\mathrm{S}$. epidermidis.
Table 2 Percentage of Inhibited Area Calculated on the Total Area of Each Single Well

\begin{tabular}{|l|l|}
\hline Carbons Mesoporous Nanomaterials & \% of Inhibited Area \\
\hline C3 & 0 \\
C3Ag2 & $4.4 \pm 0.6$ \\
C3Ag10 & $13.1 \pm 2.3$ \\
\hline
\end{tabular}

\section{Acknowledgements}

This project has received funding from the European Union's Horizon 2020 Research and Innovation Programme under grant agreement No. 685872-MOZART (www.mozartpro ject.eu).

\section{Disclosure}

There are no potential conflicts of interest to declare.

\section{References}

1. Järbrink K, Ni G, Sönnergren H, et al. The humanistic and economic burden of chronic wounds: a protocol for a systematic review. Syst Rev. 2017;6(1):15. doi:10.1186/s13643-016-0400-8

2. Frykberg RG, Banks J. Challenges in the treatment of chronic wounds. Adv Wound Care. 2015;4(9):560-582. doi:10.1089/wound.2015.0635

3. Velnar T, Bailey T, Smrkolj V. The wound healing process: an overview of the cellular and molecular mechanisms. J Int Med Res. 2009;37:1528-1542. doi:10.1177/147323000903700531

4. Mofazzal Jahromi MA, Sahandi Zangabad P, Moosavi Basri SM, et al. Nanomedicine and advanced technologies for burns: preventing infection and facilitating wound healing. Adv Drug Deliv Rev. 2018;1 (123):33-64. doi:10.1016/j.addr.2017.08.001

5. Mosser DM, Edwards JP. Exploring the full spectrum of macrophage activation. Nat Rev Immunol. 2008;8(12):958-969. doi:10.1038/nri2448

6. Morán GAG, Parra-Medina R, Cardona AG, Ronderos PQ, Rodríguez ÉG. Cytokines, Chemokines and Growth Factors. 1st ed, (Anaya JM, Shoenfeld Y, Rojas-Villarraga A. et al., editors). Bogota: El Rosario University Press; 2013; 133-164

7. Jones SG, Edwards R, Thomas DW. Inflammation and wound healing: the role of bacteria in the immuno-regulation of wound healing. Int J Low Extrem Wounds. 2004;3(4):201-208. doi:10.1177/1534734604271810

8. Lau PS, Bidin N, Islam S, et al. Influence of gold nanoparticles on wound healing treatment in rat model: photobiomodulation therapy. Lasers Surg Med. 2017;49(4):380-386. doi:10.1002/lsm.22614

9. Arafa MG, El-Kased RF, Elmazar MM. Thermoresponsive gels containing gold nanoparticles as smart antibacterial and wound healing agents. Sci Rep. 2018;8:13674. doi:10.1038/s41598-018-31895-4

10. Oyarzun-Ampuero F, Vidal A, Concha M, Morales J, Orellana S, MorenoVilloslada I. Nanoparticles for the treatment of wounds. Curr Pharm Des. 2015;21(29):4329-4341. doi:10.2174/1381612821666150901104601

11. Politano AD, Campbell KT, Rosenberger LH, Sawyer RG. Use of silver in the prevention and treatment of infections: silver review. Surg Infect (Larchmt). 2013;14(1):8-20. doi:10.1089/sur.2011.097

12. Martínez-Castañón GA, Niño-Martínez N, Martínez-Gutierrez F, Martínez-Mendoza JR, Ruiz F. Synthesis and antibacterial activity of silver nanoparticles with different sizes. $J$ Nanopart Res. 2008;10 (8):1343-1348. doi:10.1007/s11051-008-9428-6

13. Pal S, Tak YK, Song JM. Does the antibacterial activity of silver nanoparticles depend on the shape of the nanoparticle? A study of the gram-negative bacterium Escherichia coli. J Biol Chem. 2007;73 (6):1712-1720. doi:10.1128/AEM.02218-06 
14. Sau TK, Rogach AL. Complex-Shaped Metal Nanoparticles: BottomUp Syntheses and Applications. Wiley-VCH Verlag GmbH \& Co. KGaA; 2012. doi:10.1002/9783527652570

15. Marambio-Jones C, Hoek EMV. A review of the antibacterial effects of silver nanomaterials and potential implications for human health and the environment. $J$ Nanopart Res. 2010;12(5):1531-1551. doi:10.1007/s11051-010-9900-y

16. Chen Y, Shi J. Mesoporous carbon biomaterials. Sci China Mater. 2015;58(3):241-257. doi:10.1007/s40843-015-0037-2

17. Zhao Q, Lin Y, Han N, et al. Mesoporous carbon nanomaterials in drug delivery and biomedical application. Drug Deliv. 2017;24 (sup1):94-107. doi:10.1080/10717544.2017.1399300

18. Ryoo R, Joo SH, Jun S. Synthesis of highly ordered carbon molecular sieves via template-mediated structural transformation. J Phys Chem B. 1999;103(37):7743-7746. doi:10.1021/jp991673a

19. Jun S, Joo SH, Ryoo R, et al. Synthesis of new, nanoporous carbon with hexagonally ordered mesostructure. J Am Chem Soc. 2000;122 (43):10712-10713. doi:10.1021/ja002261e

20. Zhao D, Feng J, Huo Q, et al. Triblock copolymer syntheses of mesoporous silica with periodic 50 to 300 angstrom pores. Science. 1998;279(5350):548-552. doi:10.1126/science.279.5350.548

21. Shin HJ, Ryoo R, Kruk M, Jaroniec M. Modification of SBA-15 pore connectivity by high-temperature calcination investigated by carbon inverse replication. Chem Commun. 2001;340-349. doi:10.1039/ b009762o

22. Lu AH, Li WC, Schmidt W, Schüth F. Template synthesis of large pore ordered mesoporous carbon. Microporous Mesoporous Mater. 2005;80(1-3):117-128. doi:10.1016/j.micromeso.2004.12.007

23. Hammer Ø, Harper D, Ryan P. Past: paleontological statistics software package for education and data analysis. Paleontol Electron. 2001;4(1):9.

24. Karavasili C, Amanatiadou EP, Sygellou L, et al. Development of new drug delivery system based on ordered mesoporous carbons: characterisation and cytocompatibility studies. $J$ Mater Chem B. 2013;1(25):3167-3174. doi:10.1039/c3tb20304b

25. Khan MAM, Kumar S, Ahamed M, Alrokayan SA, AlSalhi MS. Structural and thermal studies of silver nanoparticles and electrical transport study of their thin films. Nanoscale Res Lett. 2011;6(1):434. doi:10.1186/1556-276X-6-434

26. Agasti N, Kaushik NK. One pot synthesis of crystalline silver nanoparticles. Am J Nanomater. 2014;2(1):4-7. doi:10.12691/ajn-2-1-2

27. Lee JH, El-Fiqi A, Mandakhbayar N, Lee HH, Kim HW. Drug/ion co-delivery multi-functional nanocarrier to regenerate infected tissue defect. Biomaterials. 2017;142:62-76. doi:10.1016/j.biomaterials. 2017.07.014

28. Hackenberg S, Scherzed A, Kessler M, et al. Silver nanoparticles: evaluation of DNA damage, toxicity and functional impairment in human mesenchymal stem cells. Toxicol Lett. 2011;201(1):27-33. doi:10.1016/j.toxlet.2010.12.001

29. Manshian BB, Jimenez J, Himmelreich U, Soenen SJ. Presence of an immune system increases anti-tumor effect of $\mathrm{Ag}$ nanoparticle treated mice. Adv Healthc Mater. 2017;6(1):1601099. doi:10.1002/adhm. 201601099

30. Mishra AR, Zheng J, Tang X, Goering PL. Silver nanoparticle-induced autophagic-Lysosomal disruption and NLRP3-inflammasome activation in HepG2 cells is size-dependent. Toxicol Sci. 2016;150(2):473-487. doi:10.1093/toxsci/kfw011

31. Park EJ, Bae E, Yi J, et al. Repeated-dose toxicity and inflammatory responses in mice by oral administration of silver nanoparticles. Environ Toxicol Pharmacol. 2010;30(2):162-168. doi:10.1016/j.etap.2010.05.004

32. Tian J, Wong KKY, Ho CM, et al. Topical delivery of silver nanoparticles promotes wound healing. ChemMedChem. 2007;2 (1):129-136. doi:10.1002/cmdc.200600171

33. Wong KKY, Cheung SOF, Huang L, et al. Further evidence of the anti-inflammatory effects of silver nanoparticles. ChemMedChem. 2009;4(7):1129-1135. doi:10.1002/cmdc.200900049
34. Kwan KHL, Liu X, To MKT, Yeung KWK, Ho CM, Wong KKY. Modulation of collagen alignment by silver nanoparticles results in better mechanical properties in wound healing. Nanomed Nanotechnol Biol Med. 2011;7(4):497-504. doi:10.1016/j.nano.2011.01.003

35. Liu X, Lee PY, Ho CM, et al. Silver nanoparticles mediate differential responses in keratinocytes and fibroblasts during skin wound healing. ChemMedChem. 2010;5(3):468-475. doi:10.1002/cmdc.200900502

36. Seo SB, Dananjaya SHS, Nikapitiya C, et al. Silver nanoparticles enhance wound healing in zebrafish (Danio rerio). Fish Shellfish Immunol. 2017;68:536-545. doi:10.1016/j.fsi.2017.07.057

37. Pakyari M, Farrokhi A, Maharlooei MK, Ghahary A. Critical role of transforming growth factor beta in different phases of wound healing. Adv Wound Care. 2013;2(5):215-224. doi:10.1089/wound.2012.0406

38. Kulkarni AB, Huh CG, Becker D, et al. Transforming growth factor beta 1 null mutation in mice causes excessive inflammatory response and early death. Proc Natl Acad Sci U S A. 1993;90(2):770-774. doi:10.1073/pnas.90.2.770

39. Ferrari G, Cook BD, Terushkin V, Pintucci G, Mignatti P. Transforming growth factor-beta 1 (TGF- $\beta 1$ ) induces angiogenesis through vascular endothelial growth factor (VEGF)-mediated apoptosis. J Cell Physiol. 2009;219(2):449-458. doi:10.1002/jcp.21706

40. Clark RAF, McCoy GA, Folkvord JM, McPherson JM. TGF- $\beta 1$ stimulates cultured human fibroblasts to proliferate and produce tissuelike fibroplasia: a fibronectin matrix-dependent event. $J$ Cell Physiol. 1997;170:5. doi:10.1002/(SICI)1097-4652(199701)170:1<69:: AID-JCP8 $>3.0 . \mathrm{CO} ; 2-\mathrm{J}$

41. Xiao L, Du Y, Shen Y, He Y, Zhao H, Li Z. TGF-beta 1 induced fibroblast proliferation is mediated by the FGF-2/ERK pathway. Front Biosci. 2012;17:2667-2674. doi:10.2741/4077

42. Verrecchia F, Mauviel A. Transforming growth factor- $\beta$ signaling through the Smad pathway: role in extracellular matrix gene expression and regulation. $J$ Invest Dermatol. 2002;118(2):211-215. doi:10.1046/j.1523-1747.2002.01641.x

43. White LA, Mitchell TI, Brinckerhoff CE. Transforming growth factor $\beta$ inhibitory element in the rabbit matrix metalloproteinase-1 (collagenase-1) gene functions as a repressor of constitutive transcription. Biochim Biophys Acta - Gene Struct Expr. 2000;1490(3):259-268. doi:10.1016/S0167-4781(00)00002-6

44. Leivonen SK, Lazaridis K, Decock J, Chantry A, Edwards DR, Kähäri VM. TGF- $\beta$-elicited induction of tissue inhibitor of metalloproteinases (TIMP)-3 expression in fibroblasts involves complex interplay between Smad3, p38 $\alpha$, and ERK1/2. Biochim Biophys Acta. 2013;1490(3):259-268. doi:10.1371/journal.pone.0057474

45. Qureshi HY, Sylvester J, El Mabrouk M, Zafarullah M. TGF- $\beta$ induced expression of tissue inhibitor of metalloproteinases-3 gene in chondrocytes is mediated by extracellular signal-regulated kinase pathway and Sp1 transcription factor. J Cell Physiol. 2005;203 (2):345-352. doi:10.1002/jep.20228

46. Luo DD, Fielding C, Phillips A, Fraser D. Interleukin-1 beta regulates proximal tubular cell transforming growth factor beta-1 signalling. Nephrol Dial Transplant. 2009;24(9):2655-2665. doi:10.1093/ndt/gfp208

47. Das L, Levine AD. TGF- $\beta$ inhibits IL-2 production and promotes cell cycle arrest in TCR-activated effector/memory T cells in the presence of sustained TCR signal transduction. J Immunol. 2014;180 (3):1490-1498. doi:10.4049/jimmunol.180.3.1490

48. Han HS, Jun HS, Utsugi T, Yoon JW. Molecular role of TGF- $\beta$, secreted from a new type of CD4+ suppressor T cell, NY4.2, in the prevention of autoimmune IDDM in NOD mice. J Autoimmun. 1997;10(3):299-307. doi:10.1006/jaut.1997.0137

49. An Y, Liu WJ, Xue P, et al. Autophagy promotes MSC-mediated vascularization in cutaneous wound healing via regulation of VEGF secretion article. Cell Death Dis. 2018;9:58. doi:10.1038/s41419-017-0082-8

50. Xiao M, Li L, Li C, et al. Role of autophagy and apoptosis in wound tissue of deep second-degree burn in rats. Acad Emerg Med. 2014;21 (4):383-391. doi:10.1111/acem.12352 
51. Li L, Xiao M. Role of autophagy in burn wound progression and wound healing. In: Gorbunov NV, Schneider M, editors. Autophagy in Current Trends in Cellular Physiology and Pathology. IntechOpen;2016. doi: $10.5772 / 63711$

52. Xiao M, Li L, Hu Q, et al. Rapamycin reduces burn wound progression by enhancing Autophagy in deep second-degree burn in rats. Wound Repair Regen. 2013;21(6):852-859. doi:10.1111/wrr.12090

53. Shi J, Shi S, Wu B, et al. Autophagy protein LC3 regulates the fibrosis of hypertrophic scar by controlling Bcl-xL in dermal fibroblasts. Oncotarget. 2017;8(55):93757-93770. doi:10.18632/oncotarget.20771

54. Lin J, Liu Y, Wu H, et al. Key role of TFEB nucleus translocation for silver nanoparticle-induced cytoprotective autophagy. Small. 2018;14:13. doi:10.1002/smll.201703711

55. Xu Y, Wang L, Bai R, Zhang T, Chen C. Silver nanoparticles impede phorbol myristate acetate-induced monocyte-macrophage differentiation and autophagy. Nanoscale. 2015;7(38):16100-16109. doi:10.1039/ c5nr04200c

56. Gibbs S. In vitro irritation models and immune reactions. Skin Pharmacol Physiol. 2009;22(2):103-113. doi:10.1159/000178869

57. Duan X, Peng D, Zhang Y, et al. Sub-cytotoxic concentrations of ionic silver promote the proliferation of human keratinocytes by inducing the production of reactive oxygen species. Front Med. 2018;12(3):289-300. doi:10.1007/s11684-017-0550-7

58. Patel GK, Wilson CH, Harding KG, Finlay AY, Bowden PE. Numerous keratinocyte subtypes involved in wound re-epithelialization. J Invest Dermatol. 2006;126(2):497-502. doi:10.1038/sj.jid.5700101

59. Kirfel J, Magin TM, Reichelt J. Keratins: a structural scaffold with emerging functions. Cell Mol Life Sci. 2003;60(1):56-71. doi:10.1007/s000180300004

60. Takahashi K, Yan B, Yamanishi K, Imamura S, Coulombe PA. The two functional keratin 6 genes of mouse are differentially regulated and evolved independently from their human orthologs. Genomics. 1998;53(2):170-183. doi:10.1006/geno.1998.5476

61. Giangreco A, Jensen KB, Takai Y, Miyoshi J, Watt FM. Necl2 regulates epidermal adhesion and wound repair. Development. 2009;136(20):3505-3514. doi:10.1242/dev.038232

62. Paladini RD, Takahashi K, Bravo NS, Coulombe PA. Onset of re-epithelialization after skin injury correlates with a reorganization of keratin filaments in wound edge keratinocytes: defining a potential role for keratin 16. J Cell Biol. 1996;132(3):381-397. doi:10.1083/jcb.132.3.381

63. Freedberg IM, Tomic-Canic M, Komine M, Blumenberg M. Keratins and the keratinocyte activation cycle. J Invest Dermatol. 2001;116 (5):633-640. doi:10.1046/j.1523-1747.2001.01327.x

64. Ramirez H, Patel SB, Pastar I. The role of TGF $\beta$ signaling in wound epithelialization. Adv Wound Care. 2013;3(7):482-491. doi:10.1089/ wound.2013.0466

65. Eckert RL, Yaffe MB, Crish JF, Murthy S, Rorke EA, Welter JF. Involucrin-structure and role in envelope assembly. J Invest Dermatol. 1993;100(5):613-617. doi:10.1111/1523-1747.ep12472288

66. Nemes Z, Marekov LN, Steinert PM. Involucrin Cross-linking by Transglutaminase 1. J Biol Chem. 1999;274(16):11013-11021. doi:10.1074/jbc.274.16.11013

67. Deucher A, Efimova T, Eckert RL. Calcium-dependent involucrin expression is inversely regulated by protein kinase $\mathrm{C}(\mathrm{PKC}) \alpha$ and $\mathrm{PKC} \delta . J$ Biol Chem. 2002;277(19):17032-17040. doi:10.1074/jbc.M109076200

68. Deyrieux AF, Wilson VG. In vitro culture conditions to study keratinocyte differentiation using the HaCaT cell line. Cytotechnology. 2007;113(5):851-855. doi:10.1007/s10616-007-9076-1

69. Löffek S, Schilling O, Franzke C-W. Biological role of matrix metalloproteinases: a critical balance. Eur Respir J. 2011;38(1):191-208. doi:10.1183/09031936.00146510

70. Gill SE, Parks WC. Metalloproteinases and their inhibitors: regulators of wound healing. Int J Biochem Cell Biol. 2008;40(6-7):1334-1347. doi:10.1016/j.biocel.2007.10.024
71. McCawley LJ, O’Brien P, Hudson LG. Epidermal growth factor (EGF)and scatter factor/hepatocyte growth factor (SF/HGF)- mediated keratinocyte migration is coincident with induction of matrix metalloproteinase (MMP)-9. J Cell Physiol. 1998;176(2):255-265. doi:10.1002/(SICI)10974652(199808)176:2<255::AID-JCP4>3.0.CO;2-N

72. Bove PF, Wesley UV, Greul AK, Hristova M, Dostmann WR, Van Der Vliet A. Nitric oxide promotes airway epithelial wound repair through enhanced activation of MMP-9. Am J Respir Cell Mol Biol. 2007;36(2):138-146. doi:10.1165/rcmb.2006-0253SM

73. Handsley MM, Edwards DR. Metalloproteinases and their inhibitors in tumor angiogenesis. Int $J$ Cancer. 2005;115(6):849-860. doi: $10.1002 /$ ijc. 20945

74. Mohammed FF, Smookler DS, Taylor SEM, et al. Abnormal TNF activity in Timp3-/-mice leads to chronic hepatic inflammation and failure of liver regeneration. Nat Genet. 2004;36(9):969-977. doi:10.1038/ng1413

75. Qi JH, Ebrahem Q, Moore N, et al. A novel function for tissue inhibitor of metalloproteinases-3 (TIMP3): inhibition of angiogenesis by blockage of VEGF binding to VEGF receptor-2. Nat Med. 2003;9 (4):407-415. doi: $10.1038 / \mathrm{nm} 846$

76. Saunders WB, Bohnsack BL, Faske JB, et al. Coregulation of vascular tube stabilization by endothelial cell TIMP-2 and pericyte TIMP-3. J Cell Biol. 2006;175(1):179-191. doi:10.1083/jcb.200603176

77. Johnson KE, Wilgus TA. Vascular endothelial growth factor and angiogenesis in the regulation of cutaneous wound repair. $A d v$ Wound Care. 2014;3(10):647-661. doi:10.1089/wound.2013.0517

78. Hotowy A, Sawosz E, Pineda L, Sawosz F, Grodzik M, Chwalibog A. Silver nanoparticles administered to chicken affect VEGFA and FGF2 gene expression in breast muscle and heart. Nanoscale Res Lett. 2012;7(1):418. doi:10.1186/1556-276X-7-418

79. Maulik N, Das DK. Redox signaling in vascular angiogenesis. Free Radic Biol Med. 2002;33(8):1047-1060. doi:10.1016/S08915849(02)01005-5

80. Kim YW, Byzova TV. Oxidative stress in angiogenesis and vascular disease. Blood. 2014. doi:10.1182/blood-2013-09-512749

81. Augustine R, Dalvi YB, Yadu Nath VK, et al. Yttrium oxide nanoparticle loaded scaffolds with enhanced cell adhesion and vascularization for tissue engineering applications. Mater Sci Eng C. 2019;103:109801. doi:10.1016/j.msec.2019.109801

82. Augustine R, Dalvi YB, Dan P, et al. Nanoceria can act as the cues for angiogenesis in tissue-engineering scaffolds: toward next-generation in situ tissue engineering. ACS Biomater Sci Eng. 2018;4:4338-4353. doi:10.1021/acsbiomaterials.8b01102

83. Mroczek-Sosnowska N, Sawosz E, Vadalasetty KP, et al. Nanoparticles of copper stimulate angiogenesis at systemic and molecular level. Int J Mol Sci. 2015;16:4838-4849. doi:10.3390/ijms 16034838

84. Augustine R, Dominic EA, Reju I, Kaimal B, Kalarikkal N, Thomas $\mathrm{S}$. Investigation of angiogenesis and its mechanism using zinc oxide nanoparticle-loaded electrospun tissue engineering scaffolds. RSC Adv. 2014;4:51528-51536. doi:10.1039/ c4ra07361d

85. Augustine R, Nethi SK, Kalarikkal N, Thomas S, Patra CR. Electrospun polycaprolactone (PCL) scaffolds embedded with europium hydroxide nanorods (EHNs) with enhanced vascularization and cell proliferation for tissue engineering applications. J Mater Chem B. 2017;5:4660-4672. doi:10.1039/c7tb00518k

86. Behravan M, Hossein Panahi A, Naghizadeh A, Ziaee M, Mahdavi R, Mirzapour A. Facile green synthesis of silver nanoparticles using Berberis vulgaris leaf and root aqueous extract and its antibacterial activity. Int J Biol Macromol. 2019;124:148-154. doi:10.1016/j. ijbiomac.2018.11.101

87. Gunasekaran T, Nigusse T, Dhanaraju MD. Silver nanoparticles as real topical bullets for wound healing. J Am Coll Clin Wound Spec. 2011;3(4):82-96. doi:10.1016/j.jcws.2012.05.001 
88. Percival SL, Bowler PG, Russell D. Bacterial resistance to silver in wound care. J Hosp Infect. 2005;60(1):1-7. doi:10.1016/j.jhin. 2004.11.014

89. Rupp ME, Archer GL. Coagulase-negative staphylococci: pathogens associated with medical progress. Clin Infect Dis. 1994;19:231-245. doi:10.1093/clinids/19.2.231
90. Pazos-Ortiz E, Roque-Ruiz JH, Hinojos-Márquez EA, et al. Dosedependent antimicrobial activity of silver nanoparticles on polycaprolactone fibers against gram-positive and gram-negative bacteria. J Nanomater. 2017;2017:1-9. doi:10.1155/2017/4752314

\section{Publish your work in this journal}

The International Journal of Nanomedicine is an international, peerreviewed journal focusing on the application of nanotechnology in diagnostics, therapeutics, and drug delivery systems throughout the biomedical field. This journal is indexed on PubMed Central, MedLine, CAS, SciSearch ${ }^{\mathbb{R}}$, Current Contents ${ }^{\mathbb{R}} /$ Clinical Medicine, $^{-}$
Journal Citation Reports/Science Edition, EMBase, Scopus and the Elsevier Bibliographic databases. The manuscript management system is completely online and includes a very quick and fair peer-review system, which is all easy to use. Visit http://www.dovepress.com/ testimonials.php to read real quotes from published authors. 